\title{
Resilience of agricultural systems facing increased salinity intrusion in deltaic coastal areas of Vietnam
}

\author{
Minh Tu Nguyen $^{1}$, Fabrice G. Renaud $^{1,2}$, Zita Sebesvari $^{1}$ and Duy Can Nguyen $^{3}$
}

\begin{abstract}
The resilience concept has provided a new insight and approach to the conventional perspective of agricultural management by emphasizing the need to maintain a diversity of future options to adapt to inevitable and often unpredictable changes. The concept has been taken up by various academic disciplines and development sectors, yet ways to define and operationalize resilience as a measurable concept are still being developed. We contributed to this ongoing effort by implementing a subjective resilience assessment method based on farmers' perceptions of three resilience components: (1) the sensitivity of their agricultural systems to increased salinity intrusion, (2) the capacity to recover from salinity damage, and (3) the capacity to change to other systems if salinity increases in the future. We conducted 27 in-depth interviews with local and national authorities, 11 focus group discussions, and 118 semistructured and 219 structured interviews with farmers in case study villages located along salinity transects in the Mekong Delta and at different distances to sea dikes in the Red River Delta in Vietnam in 2015-2016. Results from the subjective resilience assessment reveal that none of the agricultural systems studied systematically scored higher than the other systems on all three resilience components, implying that an increase in one resilience component by switching agricultural systems would negatively affect others. Agricultural responses to this salinity problem will influence current and long-term adaptability of the systems to future changes in salinity intrusion and other social-ecological developments in the deltas. Improving resilience components, e.g., through policies and interventions, resource allocation, and farming system changes, to sustain agricultural production or facilitate transformation to alternative systems when necessary is critically important for agricultural systems facing stress. Complementing subjective resilience assessments with qualitative data is thus crucial for understanding the drivers of resilience to improve components of resilience for agricultural systems in the respective deltas.
\end{abstract}

Key Words: agricultural systems; salinity intrusion; subjective resilience assessment; Vietnam

\section{INTRODUCTION}

The worst drought and salinity intrusion in 90 years took place during the dry season of 2015-2016 in Vietnam with substantial impacts on agricultural production in the country (United Nations Development Programme [UNDP] 2016). An estimated 2 million people experienced income losses, and millions of people suffered from a lack of drinking and domestic water supplies (UNDP 2016). In the Mekong Delta (MKD), where 11 out of 13 provinces had to declare a state of emergency, increased drought and salinity intrusion caused heavy crop losses and infrastructure damages (CGIAR Research Program on Climate Change, Agriculture and Food Security-Southeast Asia [CCAFS-SEA] 2016). This increase in salinity intrusion was partially attributed to the strong El Niño event, which caused a rise in temperature and significant changes in rainfall patterns and river flows regionally. However, other factors influenced the severity of salinity intrusion in the delta, including a lack of long-term projection of salinity trends for salinity preparedness, a decline of river flows and water storage capacity because of the construction of upstream dams and reservoirs, and deficiencies in the effectiveness of response measures locally such as irrigation management and salinity monitoring (CCAFS-SEA 2016, Anh 2017). In the coastal areas of the Red River Delta (RRD), which is the second largest delta of Vietnam, salinity intrusion also negatively affects rice yields and poses challenges to irrigation because of the necessary shift of irrigation intake gates farther upstream (Dat et al. 2014, Yen et al. 2017). A further increase in salinity intrusion is predicted for both the Mekong and Red River deltas because of the alteration of rainfall patterns, changing river flows, and sea level rise (Carew-Reid 2008, Hien et al. 2010, Dat et al. 2011). In addition, anthropogenic activities such as dam construction on the respective river systems and groundwater extraction locally have the potential to further accelerate the impact of salinity intrusion on the delta systems (Wagner et al. 2012, Hai and Lee 2015).

The Red River and Mekong deltas are the main agricultural production areas of Vietnam as these coastal deltas support a large diversity of agricultural systems and contribute $71.2 \%$ of the rice, $86.3 \%$ of the farmed aquaculture, and $64.7 \%$ of the fruit production of the country (Ministry of Agriculture and Rural Development 2013, General Statistics Office [GSO] 2015). The two deltas are historically managed in different ways in terms of addressing salinity intrusion and other natural hazards to maintain agricultural production (Renaud and Kuenzer 2012). In the MKD, which is largely influenced by tides, farmers have adapted to the seasonal changing salinity conditions by adopting different farming systems along salinity gradients, e.g., cultivation of two or three rice crops per year in the freshwater zone and implementation of rotational rice aquaculture, year-round aquaculture, and upland crops in the brackish and saline water zones close to the coast. In the RRD, which has a higher topography and less tide-dominated environment than the MKD, agricultural production is principally protected from salinity intrusion by a system of sea dikes and sluice gates developed over the last thousand years (Tessier 2011). In the MKD, several salinity-control structures such as sluice gates and river dikes were

${ }^{1}$ United Nations University, Institute for Environment and Human Security (UNU-EHS), ${ }^{2}$ School of Interdisciplinary Studies, University of Glasgow, Dumfries, UK, ${ }^{3}$ College of Rural Development, Can Tho University, Can Tho City, Vietnam 
also established in the coastal zone of the delta in the recent past (Tuan et al. 2007, Käkönen 2008). These protective infrastructures in both deltas are principally aimed to extend the salt-free period and limit the areas of salinity intrusion for intensive rice production. Currently, the central government has dedicated 3.76 million ha of agricultural land of the country to rice production to secure national food security and increase exports (Smajgl et al. 2015, Government of Vietnam 2016).

Against the background of increased salinity intrusion, agricultural systems in the RRD and MKD have been increasingly influenced by social-ecological processes at and beyond the delta level. In the basins of both deltas, several dams and reservoirs have been constructed or are planned (Mekong River Commission 2011, Vinh et al. 2014). These engineered structures have reduced the sediment loads and altered the hydrologic regimes of the rivers, which consequently caused significant difficulties for agricultural production in the deltas (Kummu and Varis 2007, Vinh et al. 2014). From an institutional perspective, many changes in agricultural systems in the deltas over the last decades were driven by national policies. Other major socioeconomic drivers include increasing migration and integration of farming systems to global markets, which has accelerated since the Doi Moi, i.e., economic and political renovation starting in 1986 (Tu et al. 2019). As results of these processes, agricultural systems in the deltas have changed considerably toward intensification, for example, by increasing annual crop production and input use, and diversification of rice production with more aquaculture and upland crops (Käkönen 2008, van Dijk et al. 2013). These adaptation processes in agricultural systems to changing deltaic social-ecological conditions could lock in some areas of the deltas to particular production systems, making shifts to alternative systems or reversing to the original farming systems complicated, if not impossible. Examining the sensitivity of agricultural systems to increased salinity intrusion and the capacities to recover from salinity damage and shift to other farming systems when necessary is particularly important for informing the management of such changes and, in particular, avoiding the development of path dependency (Bennett et al. 2014).

Resilience is a concept that is popularly used to illustrate capacities of systems to absorb disturbances and recover from damages to persist within the same trajectory, as well as the ability to change and transform to a new system state (Carpenter et al. 2001, Folke 2016). The concept has emerged and is being developed from/into various academic disciplines with different meanings and understandings (Alexander 2013, Folke 2016). The first resilience perspective considers a system to be static and assumes that it should "bounce back" to normality/a steady-state condition once the disturbance/perturbation is removed or overcome, for instance, the capacity of an agroecosystem or critical infrastructure to return to its original state after disturbances (Carpenter et al. 2001, Schwab et al. 2016). This "engineering perspective" of resilience focuses on the reduction of exposure/ sensitivity of systems to disturbances so that they stay in the same regime. This perspective can be considered a flip side of vulnerability (Chelleri et al. 2015). In ecological and socialecological resilience, the systems are considered to have multiple basins of attractions and are able to switch from one functional state to another (Folke 2016). Ecological resilience perspective focuses on the capacity of the systems to withstand shocks and recover after the perturbations before moving into an alternative state with different structures and feedbacks (Walker et al. 2004). Social-ecological resilience nevertheless is not only the capacity of the systems to buffer and bounce back, but more importantly, the ability to learn from change and create new desirable development pathways under disturbances (Nelson et al. 2007, Folke 2016).

In agricultural management, the resilience concept has offered a new approach to the conventional farm management that not only addresses the capacity of the farming system to maintain functionality under shocks but also adds the value of proactive changes and transformation into new systems to address future challenges and take advantage of opportunities that arise (Nelson et al. 2007, Darnhofer 2014). The latter perspective of resilience emphasizes the need to maintain natural capital, redundancy, and flexibility of systems for future adaptation (Walker et al. 2010, Bennett et al. 2014). Management for resilient agriculture thus requires an understanding of which farming practices to implement to maintain the existing system and when and how to adapt and transform into alternative systems when necessary (Bennett et al. 2014). Despite the widespread application of the concept in various disciplines, resilience has been popularly used as a concept for understanding and managing change, although few studies have attempted to assess and measure resilience in practice (Kien and James 2013, Overseas Development Institute [ODI] 2016). We therefore aimed to operationalize the resilience concept by assessing the resilience of different agricultural systems in the Mekong and Red River deltas to increased salinity levels based on farmers' perspectives, as well as to characterize factors that influence the resilience of these systems.

Although there is variation among disciplines, resilience definitions share similarities in key elements such as types of disturbances, system/unit of analysis, pre-event action, damage limitation, and managing change (ODI 2016). For example, Kien and James (2013) defined the resilience of households in the MKD to floods as comprising three components: (1) confidence in securing basic consumption such as food and income during floods and recovering after the event, (2) confidence in securing homes, and (3) interest in learning and practicing new flood-based farming practices. Resilience is defined by Bennett et al. (2014) and Darnhofer (2014) as the ability of farming systems to buffer shocks and persist, as well as the capacity to adapt and transform to new systems. Following these definitions, we defined resilience of agricultural systems to increased salinity intrusion as an interplay of three components. The first component is the sensitivity of the system to increased salinity, indicating how the current farming system would be affected if salinity increased in the future. The second component relates to the recovery capacity, reflecting the ability of the system to recover after salinity damage in case of increased salinity intrusion, both spatially and temporarily, as well as in intensity. The third component is the capacity to change, illustrating the ability of the system to change to alternative farming systems if salinity were to increase even before severe impacts are felt. The first two components, i.e., the sensitivity to increased salinity intrusion and the capacity to recover, capture the first resilience perspective in terms of the ability of a system to absorb/buffer shocks and recover after disturbances to persist within the same regime. The last 
component, the capacity to change, reflects the capacity of the system to change its fundamental attributes to move to a new regime/system state to better address future challenges (Chelleri et al. 2015, Folke 2016).

\section{APPROACHES IN MEASURING AND ASSESSING RESILIENCE}

Resilience has become the background and objective for a wide range of studies and development programs, yet ways to operationalize it as a measurable concept are still being developed (Quinlan et al. 2016). In operationalization of the resilience concept, the measurements focus substantially on the use of objective indicators (Food Security Information Network [FSIN] 2014, Jones and Tanner 2017). In these measurements, resilience is deconstructed into components or capacities (Ciani and Romano 2014, Food and Agriculture Organization of the United Nations [FAO] 2014, FSIN 2014). Social-economic and environmental indicators such as household characteristics, access to loans and social networks, and soil and water characteristics that are assigned to these components or capacities are then obtained and aggregated to construct a resilience index (FSIN 2014). Researchers therefore have to understand factors that characterize the resilience of these systems (Clare et al. 2017). One limitation of this approach is that if the indices are constructed based on these predefined social-ecological characteristics, the discussion and conclusion are likely to follow these initial indicators (Levine 2014). While qualitative approaches can explore issues that the researchers have not expected, the objective indicator approaches can only quantify what researchers know about the systems, for instance, after a literature review or pretest of the questionnaires (Bernard 2000, Jones and Tanner 2017). Therefore, these approaches are widely considered as subject to manipulation and circular argument bias because they limit the understanding of which characteristics influence resilience apart from the socioeconomic and environmental factors that are used to construct the indexes themselves (Béné 2013, Clare et al. 2017, Jones and Tanner 2017). The approach is also difficult to compare across case studies because farmers at particular places and times can rely on different resources to build resilience (Béné 2013). Other alternatives and complementary approaches to objective resilience measurement such as the quantification of the cost of anticipation, impact and recovery under shocks (Béné 2013), or the subjective measurements of resilience based on respondents' perceptions (Kien and James 2013, Clare et al. 2017, Jones and Tanner 2017) are being developed. These approaches do not use the direct social-economic and environmental characteristics of the measured units to construct the resilience indexes and can therefore more readily inform which factors influence resilience (Clare et al. 2017). We applied the subjective assessment approach to quantify resilience based on the premise that farmers themselves are in the best position to understand the factors that influence the sensitivity and ability to recover and change of their farming systems, as well as their capacities to influence these resilience components (Jones and Tanner 2017).

Both subjective and objective measurements of resilience run the risk of a limited system understanding through the collection of what can be easily measured and the simplification of a multidimensional concept into a few single indices (Levine 2014, Quinlan et al. 2016). There are suggestions that resilience cannot be directly observed and a qualitative assessment of resilience is more useful (Carpenter et al. 2005, Cumming et al. 2005). Resilience can be assessed through the historical profiling of a specific place over time to understand its system dynamics and how it evolved and responded to changes, as illustrated in the wellknown resilience assessment workbooks (Resilience Alliance 2007, 2010). This approach requires a comprehensive analysis of the variables that determine the system's functions, as well as cross-scale interactions and feedbacks between the focal scale and other connected systems above and below the focal scale. Alternative approaches are based on the development of local surrogates, which are considered resilience-building blocks to assess resilience indirectly (Berkes and Seixas 2005, Marschke and Berkes 2006). Qualitative assessments can capture some aspects of a system's resilience that are difficult to quantify such as culture, well-being, or social cohesion of households and communities (Maxwell et al. 2015, Quinlan et al. 2016). Against this background, our research supplemented a subjective resilience assessment based on 5-point Likert scales to measure farmers' perceptions of the resilience components of their systems with qualitative data, allowing for a more holistic understanding of resilience. The complementarity of quantitative measurement with a qualitative assessment of resilience is crucial because it allows for a deep understanding of system dynamics, especially for issues that are embedded in the wider spatial-temporal complexities (Frankenberger and Nelson 2013, Quinlan et al. 2016). A system-wide analysis for resilience assessment can provide insights into the operation of the systems under stresses and their changes, as well as for understanding the socialecological settings that should help dictate the management of these complex systems (Biggs et al. 2012).

\section{RESEARCH AREAS AND METHODOLOGY}

\section{Research areas}

To examine the resilience of different agricultural systems to various degrees of salinity intrusion, case study research was conducted in villages located along salinity gradients in the MKD, comprising (1) villages in the freshwater zone farther inland but still exposed to salinity intrusion, (2) villages in the brackish water zone where salinity levels substantially fluctuate between the dry and wet seasons, and (3) villages in the saline water zone close to the coast where saline water occurs all year (Fig. 1; see Tu et al. 2019). In the MKD, during the dry season when the river discharge is low, tides from the South China Sea and the Gulf of Thailand can typically bring saline water up to $70 \mathrm{~km}$ inland (Tuan et al. 2007). During the wet season, the increase of river flows can push the salt water into the proximity of the mouth of the rivers (Hashimoto 2001). This seasonal fluctuation in saline water intrusion greatly influences the type of agroecosystems along the salinity gradients. In the freshwater zone, the main cropping system consists of two rice crops per year (hereafter double rice). In the brackish water zone, rice is cultivated during the wet season, and one or two shrimp seasons are cultured during the dry season, which we refer to as the rice-shrimp system. In the saline water zone, two to four shrimp seasons are cultured year-round, referred to as the shrimp system hereafter.

In the RRD, agricultural systems are less affected by salinity intrusion when compared with the MKD thanks to the construction of concrete sea dikes and sluice gates, as well as the 
Fig. 1. Research sites in the Red River (1) and Mekong (2) deltas with main farming systems indicated in parentheses.

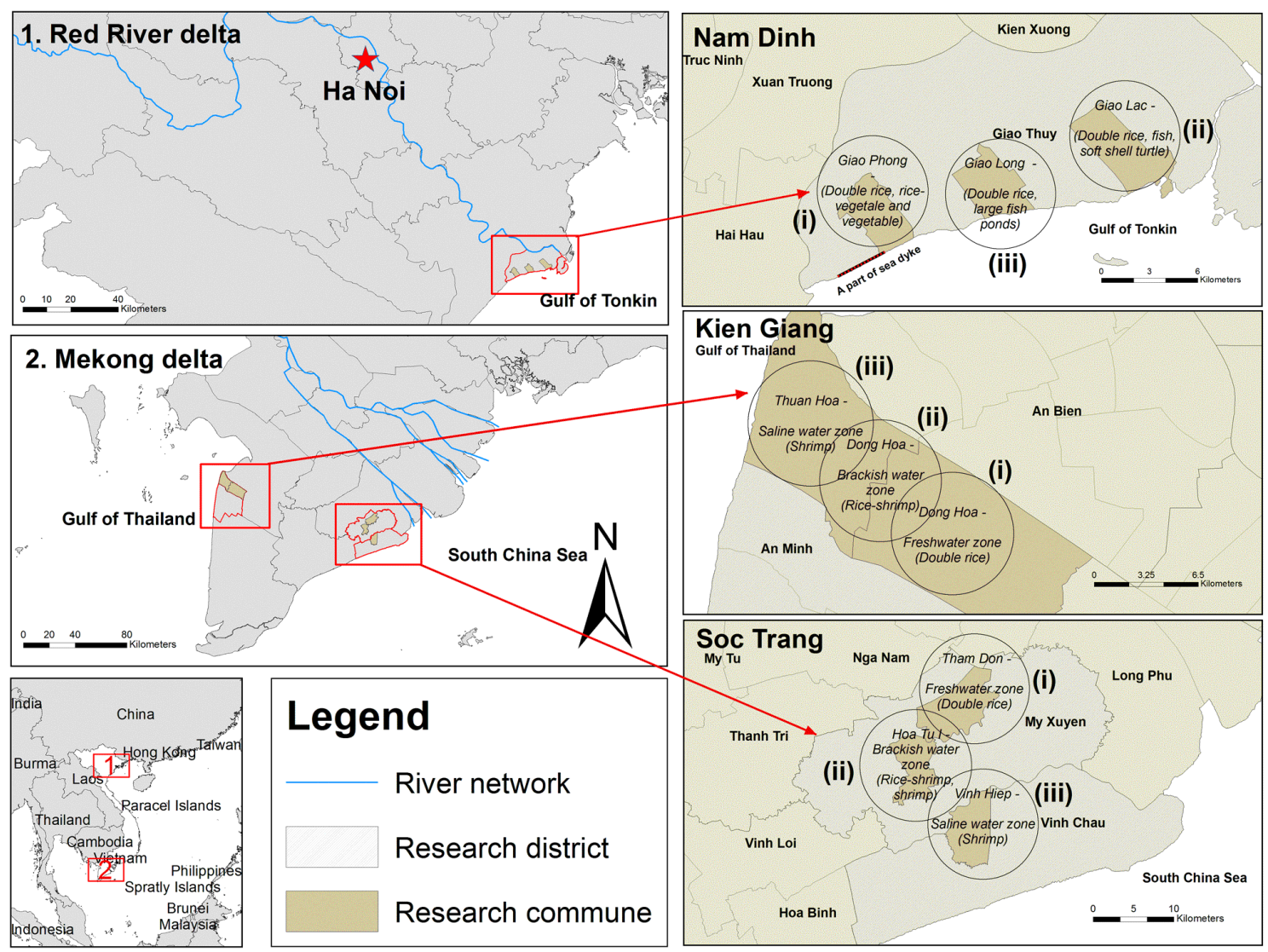

higher elevation of the coastal zone and a less tide-dominated environment (Pruszak et al. 2005, Cong et al. 2009). The existence of massive protective infrastructure turns the whole delta into a freshwater zone, and double rice can be cultivated even in areas very close to the coast. Salinity intrusion, however, still takes place through sluice gate leakages and infiltration of saline water through the sea dikes (Yen et al. 2017). In the RRD, research villages were located at different distances to the sea dikes (Fig. 1). These communities included (1) villages farther inland where double rice, rice-vegetables, and vegetables are the main farming systems; (2) villages in the middle areas of our research transect where double rice, fish pond, and soft-shell turtle systems are the dominant cropping systems; and (3) a village close to the sea dikes where double rice and large fish ponds are predominant (Fig. 1). In total, the research transects that were located in different agroecological zones within two provinces, Kien Giang and Soc Trang, were considered in the MKD, and one province, Nam Dinh, was selected in the RRD.

\section{Methodology}

Various methodologies are applied to assess subjective resilience, varying from household surveys to qualitative approaches such as focus group discussions (FGDs) and in-depth interviews (Levine 2014, ODI 2016, Jones and Tanner 2017). While no single method is able to capture resilience in all contexts, use of a wide range of methods is usually recommended (Frankenberger and Nelson 2013, FAO 2014; Table 1).

Our empirical data consisted of interview results with local authorities, FGDs, and semistructured and structured interviews with farmers conducted between September 2015 and May 2016. The subjective resilience assessment in the MKD was based on a survey of 219 randomly selected households in Kien Giang and Soc Trang from December 2015 to February 2016. In the RRD, the resilience assessment was based on 118 semistructured interviews conducted between March and April 2016. Pretests of questionnaires were conducted with 7 households in a village in close proximity to the researched villages in the MKD, and the questionnaires were then adjusted. This quantitative information was complemented with qualitative data from 80 semistructured interviews conducted in the MKD, as well as 11 FGDs with farmers and 27 in-depth interviews with local and national authorities carried out in both deltas for an understanding of the drivers of resilience (Table 2).

Structured and semistructured interviews

The subjective assessment of resilience was based on farmers' perceptions of (1) the sensitivity of their farming systems to increased salinity intrusion, (2) the capacity of their farming 
Table 1. Different approaches in resilience measurement.

\begin{tabular}{lll}
\hline \hline Measurement Approaches & References & Strengths \\
\hline $\begin{array}{l}\text { Objective resilience indices based on a } \\
\text { household survey }\end{array}$ & $\begin{array}{l}\text { Frankenberger et al. } \\
(2013), \text { Food Security }\end{array}$ & $\begin{array}{l}\text { Fixed framing of resilience and } \\
\text { standardization of measurements }\end{array}$ \\
& Information Network & across respondents, easy to compare \\
& $(2014)$ & across households and stratified \\
& & groups (Jones 2019)
\end{tabular}

Explanatory/qualitative research using focus group discussions, indepth interviews, and so forth

Subjective resilience using a household survey

Combining qualitative and quantitative approaches in resilience measurement
Toth et al. (2016), Ungar Accounts for the researcher bias in (2003)

Béné et al. (2016) Tanner et al. (2015), Jones and Tanner (201 Clare et al. (2017) Bottom-up and participatory predefined resilience indicators, reducing the questionnaire burden, the selection of resilience factors and the specific socio-cultural context in which resilience occurs (Ungar 2003) approach, removing the external and improving understanding of determinants of resilience, and enabling cross-cultural comparison of resilience (Clare et al. 2017, Jones 2019)

Beauchamp et al. (2019), Depending on the degree of

Ungar and Liebenberg qualitative or quantitative use, a (2011) mixed method approach can provide complementary information and improve an understanding of drivers of resilience (Maxwell et al. 2015)
Limitations/Challenges

Difficult to measure intangible characteristics of resilience (Clare et al. 2017), hard to understand the drivers of resilience, risk of using the same set of indicators for resilience measurement of individuals or systems with different cultural background and social-ecological settings (Jones 2019)

Methodological looseness, key informant type approaches, difficult to generalize to the whole population (Maxwell et al. 2015)

Cognitive bias in the answers (Tanner et al. 2015 , d'Errico et al. 2018) and little evidence of their validity and use for policy and practice until now (Beauchamp et al. 2019)

Challenging to synthesize information into one analysis (Maxwell et al. 2015) systems to recover from salinity damage, and (3) the capacity to change their farming systems to other systems if salinity increases in the future. Following the study of Jones and Tanner (2017), a single question with a 5-point Likert scale was asked to address each resilience component: (1) To what extent is your farming system affected if salinity intrusion increases? (2) In the case of salinity damage, to what extent can you re-engage in your farming system? (3) To what extent can you alter/convert your farming system to another system if the conditions for production change? The answers consisted of 5 scaled responses: (1) very little; (2) little; (3) average, including "neither little nor much," "do not know exactly," "it depends," and "it varies"; (4) much; and (5) very much severity (for the question on sensitivity to increased salinity intrusion) or ability (for questions on the capacities to recover and to change). Each of these questions captured 1 of the 3 components of social-ecological resilience: sensitivity of agricultural systems to increased salinity intrusion, capacity to recover, and capacity to change to a new system before severe impacts are felt. Elicited answers were noted and transcribed as were the explanations of the choices. For the rice-shrimp system in the MKD, the questions of sensitivity and recovery capacity were asked separately for rice and shrimp farming and then aggregated because rice and shrimp are exposed differently to salinity intrusion. The wealth criteria for the wealth ranking exercises were collected from the FGDs, and the ranking of all households in the village was conducted by following small groups of stakeholders, e.g., hamlet leaders, elderly farmers, and leaders of farmers' associations at the commune level. In total, 219 households in villages along the salinity gradients were interviewed in the MKD (Table 3).
Table 2. Number of interviews and focus group discussions per research site.

\begin{tabular}{lccc}
\hline \hline $\begin{array}{l}\text { Number of Interviews and } \\
\text { Focus Group Discussions }\end{array}$ & Kien Giang & Soc Trang & $\begin{array}{c}\text { Nam } \\
\text { Dinh }\end{array}$ \\
\hline Semistructured interviews & 43 & 37 & 118 \\
Structured interviews & 105 & 114 & $\mathrm{n} / \mathrm{a}$ \\
Focus group discussions & 4 & 3 & 4 \\
\hline
\end{tabular}

In the RRD, many households have not experienced salinity damage for many years, and the assessment of the sensitivity and recovery capacity of their farming systems in the case of increased salinity was difficult. Therefore, the three resilience-related components were only assessed for the double rice, fish pond, soft-shell turtle, and rice-vegetable systems, which were the most exposed systems to salinity intrusion. For the large fish pond and vegetable systems, only the capacity to change based on the 5point Likert scale was assessed. Qualitative data from the semistructured interviews, FGDs, and secondary data were subsequently employed to assess the sensitivity to increased salinity intrusion and the capacity to recover from salinity damage of these farming systems.

Focus group discussions and in-depth interviews with authorities Structured and semistructured interviews provided the primary source of information for the resilience assessment. Qualitative data from the FGDs and in-depth interviews with authorities were used to explain the results when necessary. The FGDs and indepth interviews with authorities were aimed at exploring the general agricultural conditions in the research areas, the drivers 
Table 3. Characteristics of the interviewed households in the structured (Mekong Delta, MKD) and semistructured interviews (Red River Delta, RRD).

\begin{tabular}{|c|c|c|c|c|}
\hline \multirow[t]{2}{*}{ Explanation } & \multirow[b]{2}{*}{ Mean/Median } & \multicolumn{3}{|c|}{$\begin{array}{c}\text { Mean and Median (Standard Deviations and Interquartile Ranges in } \\
\text { Parentheses) }\end{array}$} \\
\hline & & Kien Giang (MKD) & Soc Trang (MKD) & Nam Dinh (RRD) \\
\hline Number of interviewed households & & 105 & 114 & 118 \\
\hline Wealth categories (poor/average/better off) & & $28 / 58 / 19$ & $41 / 42 / 31$ & $\mathrm{n} / \mathrm{a}^{\dagger}$ \\
\hline Age of the household head (years) & Mean & $52.2(12.83)$ & $50.8(10.38)$ & $54.6(9.90)$ \\
\hline $\begin{array}{l}\text { Education of the household heads: } 1 \text {, no schooling; } 2 \text {, primary } \\
\text { school; } 3 \text {, secondary school; } 4 \text {, high school; } 5 \text {, higher education } \\
\text { (e.g., university, college, vocational degrees) }\end{array}$ & Median & $3(2-3)$ & $2(2-3)$ & $3(2-3)$ \\
\hline Percentage of male-headed households (\%) & Mean & $86.7(0.34)$ & $83.3(0.37)$ & $92.4(0.27)$ \\
\hline House size in square meters & Mean & $116(53.56)$ & $97(72.18)$ & $86(53.37)$ \\
\hline $\begin{array}{l}\text { Percentage of households that are able to access the house by } \\
\text { motorbike in both seasons }(\%)\end{array}$ & Mean & $80.0(0.40)$ & $76.3(0.43)$ & $96.6(0.18)$ \\
\hline Percentage of households that have off-farm income $(\%)^{\dagger}$ & Mean & $41.9(0.50)$ & $45.6(0.50)$ & $51.7(0.50)$ \\
\hline Percentage of households that receive remittances $(\%)$ & Mean & $10.8(0.31)$ & $17.1(0.38)$ & $36.4(0.74)$ \\
\hline Number of household members & Mean & $4.2(1.43)$ & $4.6(1.56)$ & $3.7(1.46)$ \\
\hline $\begin{array}{l}\text { Farm size in hectares (including all different fields, also of other } \\
\text { farming systems) }\end{array}$ & Mean & $2.32(1.99)$ & $1.75(1.64)$ & $0.25(1.20)$ \\
\hline
\end{tabular}

of change in agricultural systems since the end year of the war in 1975, and adaptation pathways of agricultural systems in response to future changes regarding key drivers of change (Tu et al. 2019).

\section{Data analysis}

Descriptive statistics, e.g., mean and median, were calculated using STATA (StataCorp LLC, Texas, USA). Socioeconomic and ecological characteristics of the agricultural systems were examined and compared to explain the differences of resiliencerelated components among them. Chi-square and Kruskal-Wallis tests at $p=0.05$ for nonnormal distributed data were performed for this purpose (Wooldridge 2010). Wherever the Kruskal-Wallis test found a significant difference, Dunn's tests were performed to find out which specific values of subgroups were significant from the others (Dinno 2015). The qualitative data from the FGDs and semistructured interviews were transcribed, and the text was analyzed using MAXQDA software (VERBI, Berlin, Germany); for a detailed explanation of the qualitative analyses, see Tu et al. (2019).

\section{RESULTS}

\section{Resilience of agricultural systems to increased salinity intrusion in the Mekong Delta}

The results from the resilience assessment (Table 4) reveal that the double rice system was perceived as the most sensitive system to salinity, followed by the rice-shrimp and shrimp systems. In contrast, the rice system was perceived as the system with the best recovery capacity after being affected by salinity, whereas the shrimp and rice-shrimp systems can recover least easily. Rice farmers also perceived a higher capacity to change their farming system, followed by rice-shrimp and shrimp system farmers. However, differences among the farming systems were only statistically significant in relation to the households' perceived capacity to recover (Table 4). The following sections present the sensitivity of agricultural systems to increased salinity intrusion and the capacities to recover from salinity damage and change to other systems if salinity increases in the future. The factors that characterize these resilience components were examined based on the qualitative data from the FGDs and in-depth interviews with farmers and authorities.

Table 4. Median values of resilience-related components of agricultural systems for the interviewed farmers in the Mekong Delta (interquartile ranges in parentheses). The values in the table represent a "1-5 Likert scale" standing for very little (1) to very much (5) severity (for the question on the sensitivity to increased salinity intrusion) or ability (for questions on the capacities to recover and to change). No significant difference between farming systems on the sensitivity $\left(\chi^{2}(2)=2.08, \mathrm{p}=0.353\right)$ and capacity to change $\left(\chi^{2}(2)=0.37, p=0.833\right)$; significant difference between farming systems on the capacity to recover $\left(\chi^{2}(2)=7.68, p=0.022\right)$ using the Kruskal-Wallis test. The median values with different superscripts are significantly different ( $p<0.05$, Dunn's test).

\begin{tabular}{|c|c|c|c|}
\hline $\begin{array}{l}\text { Farming } \\
\text { Systems }\end{array}$ & Sensitivity $^{\dagger}$ & $\begin{array}{c}\text { Capacity to } \\
\text { Recover }^{*}\end{array}$ & $\begin{array}{c}\text { Capacity to } \\
\text { Change }^{\S}\end{array}$ \\
\hline Rice & $2.5(2.0-3.0)$ & $4.0^{\mathrm{a}}(2.5-4.5)$ & $3.0(2.0-4.0)$ \\
\hline Rice-shrimp & $2.0(2.0-4.0)$ & $3.0^{\mathrm{b}}(2.0-4.0)$ & $2.0(2.0-4.0)$ \\
\hline Shrimp & $2.0(1.5-3.0)$ & $3.0(2.0-4.0)$ & $2.5(2.0-4.0)$ \\
\hline \multicolumn{4}{|c|}{$\begin{array}{l}\text { Median value of the first question on expected salinity impact if } \\
\text { salinity intrusion increases; lower value is better. } \\
\text { Median value of the second question on the capacity to recover after } \\
\text { salinity damage; higher value is better. } \\
\S \text { Median value of the third question on the capacity to change if the } \\
\text { conditions of production change; higher value is better. }\end{array}$} \\
\hline
\end{tabular}


Fig. 2. Cropping calendars in Kien Giang (KG) and Soc Trang (ST).

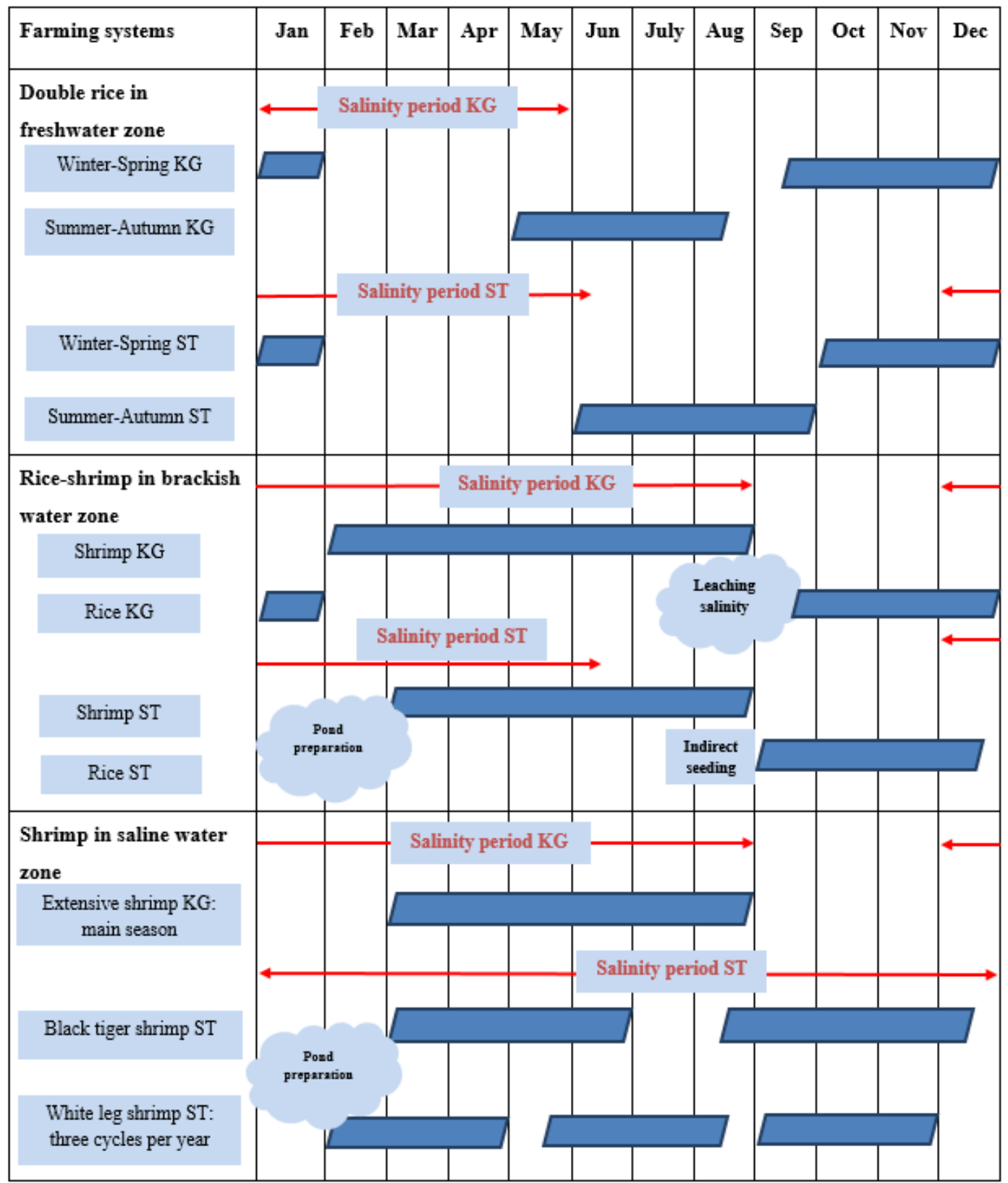

Sensitivity of agricultural systems to increased salinity intrusion Results from the structured interviews indicated that nearly $43 \%$ of rice farmers, $68 \%$ of rice-shrimp farmers, and $53 \%$ of shrimp farmers assumed that salinity intrusion would increase in the next decade. In the MKD, increased salinity intrusion would cause more impact on rice production than rice-shrimp and shrimp systems. Rice is a saline-sensitive crop, and yields can significantly decline at salinity levels above $3 \mathrm{~g} / \mathrm{L}$ even for some salt-tolerant varieties (Smajgl et al. 2015). Shrimp systems can endure relatively high levels of salinity depending on the shrimp species. The optimal growth rate is obtained at salinity levels less than $15 \mathrm{~g} / \mathrm{L}$ for white leg shrimp (Litopenaeus vannamei) and $35 \mathrm{~g} / \mathrm{L}$ for black tiger shrimp (Penaeus monodon; Briggs et al. 2004, Ye et al. 2009). The rice-shrimp system is typically less affected by salinity intrusion than double rice thanks to the adaptation of rice and shrimp systems to seasonal changes in salinity conditions (see Fig. 2). Prolonged salinity intrusion, however, can shorten the necessary time for leaching salinity after the shrimp season and before the rice season, damaging rice during its crucial development stage because of the remaining salinity content in the soil (Nhan et al. 2012, Leigh et al. 2017).

In the freshwater zone of the research areas, salinity intrusion usually affects the double rice system during the vegetative period 
of the winter-spring season, the latter lasting from September to January in Kien Giang and from October to January in Soc Trang (Fig. 2). In the semistructured interviews, rice-shrimp farmers often cultivated salt-tolerant rice varieties, whereas double rice farmers mainly adopted short-cycle varieties to be able to harvest the rice before the onset of salinity intrusion. Thus, if salinity intrusion begins to affect the rice crop, the damage is more serious for double rice systems because of the lower salinity tolerance of short-cycle rice varieties and the fact that salinity stress at the vegetative stage causes more harm than during other growth stages (Asch and Wopereis 2001).

The occurrence of a high content of sulfate and high acidity in the soil is another factor contributing to the high sensitivity of the rice system to increased salinity intrusion. In the MKD, there is evidence that the water acidity rather than salinity affects the rice cropping in areas inside the dike (Aizawa et al. 2009). During the period of high salinity levels, the sluice gates will be closed to prevent saline water from entering, leading to a lack of freshwater supply and thus falling water levels in the paddy fields (Nhan et al. 2007, Aizawa et al. 2009). The oxidation of acid sulfate soils and the release of toxic substances because of the increased exposure to oxygen damage rice production (Nhan et al. 2007, Aizawa et al. 2009). In the structured and semistructured interviews, rice-shrimp farmers usually mentioned a reduction of acidity thanks to the use of lime for pond preparation and treatment in between the rice and shrimp seasons and during the shrimp season (see also Leigh et al. 2017). As evidenced from the structured interviews, the largest field/pond of rice-shrimp and shrimp systems had a lower acid sulfate soil than double rice systems ( $\mathrm{p}<0.05$, Dunn's test).

\section{Capacity to recover from salinity damage}

In the structured interviews, the rice-shrimp system was perceived to be the least able to recover once affected, whereas the double rice and shrimp systems were deemed to be able to recover more easily (Table 4). One explanation is that rice-shrimp farmers in Kien Giang rely on rainfall for leaching salinity from the soil after the shrimp season. If the rice-shrimp system experiences damages from salinity, farmers need to wait for the onset of the rain to wash out the salinity and replant. Rice-shrimp farmers in Soc Trang have better access to the fresh water from the adjacent Hau River to eliminate salinity from the soil. However, the increased salinity levels in the river at the end of the rice season could damage the rice crop in Soc Trang, especially when replanting (see Fig. 2). Other explanations are linked to the low capacities farmers have to recover after salinity damage of the rice-shrimp systems as explained in the interviews, e.g., lower access to loans and lower off-farm income sources compared with double rice and shrimp systems (all significant at $\mathrm{p}<0.01$, chi-square test). Rice farmers in the freshwater zone can access government loans because of the government policies to promote rice production (Government of Vietnam 2012), whereas commercial shrimp farmers in the saline water zone generally can easily access loans from input sellers and traders (Ha 2012, Joffre 2015). In the freshwater zone, many farmers have off-farm jobs as hired laborers and workers thanks to being closer to the district's center, whereas in the saline water zone, farmers have more opportunities for hired labor jobs in commercial shrimp farms and fishing.
Capacity to change to other agricultural systems

The measurement of perceived capacity to change (Table 4) shows no statistical difference between systems. In the interviews and FGDs, the shrimp system often demonstrated the least capacity to change because there was no clear pathway the shrimp system could move toward apart from reversing to a riceshrimp system. There is evidence that the reversion to a riceshrimp system would also be difficult because of the modified landforms (aquaculture ponds) that need to be refilled and as a result of soil salinization from practicing intensive shrimp cultivation (Tho et al. 2008, Thuy and Ford 2010). Double rice and rice-shrimp systems have more opportunities to change trajectories if salinity increases, e.g., to rice-shrimp or ricevegetable crops for double rice systems and monoshrimp for the rice-shrimp systems.

The capacity of double rice systems to change is largely affected by government regulations. At the national level, 3.76 million ha of rice have to be maintained until 2020 to ensure food security, and each province has to maintain an assigned rice land area (Government of Vietnam 2016). In 2000, the central government implemented a restructuring policy that introduced greater flexibility and allowed the diversification of marginal rice land use to other systems such as vegetable crops and brackish aquaculture (Government of Vietnam 2000). Nevertheless, the choice of farming system is bound to specific land use planning that stipulates the area for each type of crop (Tien et al. 2006, Garschagen et al. 2012). Farmers can decide which varieties of rice or fruits to cultivate for each assigned land use category. However, a total conversion from double rice to other farming systems such as aquaculture is not encouraged (Government of Vietnam 2012). Given this institutional impediment for shifting away from double rice production, the rice system usually has fewer possibilities for changing to alternative systems when compared with rice-shrimp production.

\section{Resilience of agricultural systems to increased salinity intrusion in the Red River Delta}

Sensitivity of agricultural systems to increased salinity intrusion and capacity to recover from salinity damage

In all villages, most farmers assumed that salinity intrusion would decline in the next decade thanks to the continuous upgrading of sea dikes, sluice gates, and irrigation infrastructures. In the RRD, rice is the most salinity-affected system (Table 5) because it is exposed directly and regularly to water from the Red River. The main sources of salinity intrusion are through sluice gate leakage and salinity infiltration through sea dikes, as well as the operation of irrigation gates along the Red River, which are opened to get water inside the field if the monitored salinity level in the river is lower than $1 \mathrm{~g} / \mathrm{L}$ (Yen et al. 2017). Soft-shell turtle and fish production systems are only very slightly affected by an increase in salinity intrusion because these systems are less exposed to saline water as a result of a less regular exchange with river water (Dat et al. 2014). The increased salinity intrusion also has a low impact on vegetable and ricevegetable crops because these systems are irrigated with groundwater. Salinity intrusion in groundwater was reported during the interviews but not considered serious at that time. However, because some rice-vegetable and vegetable fields were converted from salt production fields in the past, salinity does 
Table 5. Median values of perceived sensitivity of agricultural systems to increased salinity intrusion and recovery capacity for the interviewed farmers in the Red River Delta (interquartile ranges in parentheses).

\begin{tabular}{|c|c|c|c|c|c|c|}
\hline $\begin{array}{l}\text { Perceived } \\
\text { Components }\end{array}$ & Double Rice & Rice-Vegetable & Vegetable & Fish Pond & Soft-Shell Turtle & Large Fish Pond \\
\hline Sensitivity $^{\dagger}$ & $1.0(1.0-2.0)$ & $1.0(1.0-1.0)$ & $\mathrm{n} / \mathrm{a}$ & $2.0(1.0-4.0)$ & $2.0(1.0-2.0)$ & $\mathrm{n} / \mathrm{a}$ \\
\hline $\begin{array}{l}\text { Capacity to } \\
\text { recover }^{\dagger}\end{array}$ & $4.0(3.0-5.0)$ & $4.0(2.0-5.0)$ & $\mathrm{n} / \mathrm{a}$ & $4.0(2.5-4.5)$ & $4.0(2.0-4.0)$ & $\mathrm{n} / \mathrm{a}$ \\
\hline
\end{tabular}

become a problem during droughts given that subsoil layers still contain relatively high levels of salt. For the large fish pond systems along the sea dike, salinity leakage through the sea dike exists but is not serious for fish farming. Vegetable crop, fish, and soft-shell turtle systems also have lower sensitivity to salinity when compared with rice (FAO 2002).

Farmers in all farming systems perceived a high capacity to recover from salinity damage (Table 5). During the interviews, rice farmers mentioned that they would replant the rice crop by washing out the salinity and increasing fertilizer use to compensate for the damage. Rice-vegetable and vegetable systems can also recover easily from salinity damage because farmers can switch the vegetable crops. For fish pond, soft-shell turtle, and large fish pond systems, farmers usually mentioned the use of lime and fertilizers to lower the salinity in the ponds before returning to farming activities.

\section{Capacity to change to other agricultural systems}

Regardless of the farming system, a majority of farmers in the interviews stated that they would continue their current farming systems even if they suffered two consecutive crop losses. In the interviews, when asked for a self-assessment of the capacity to change, fish pond, large fish pond, and double rice farmers noted low capacities to change, whereas rice-vegetable, vegetable, and soft-shell turtle farmers rated a higher capacity to shift to other systems (Table 6). Fish pond and large fish pond systems are usually difficult to convert back to double rice or other systems because of excavation of land and a high financial capital requirement to fill the pond. Similar to the MKD, the institutional settings that favor rice production impede shifts from double rice systems to alternative systems (Government of Vietnam 2012). For rice-vegetable and vegetable systems, farmers can easily change their systems to fruits, bonsai, rice, and flowers. During the interviews, soft-shell turtle farmers also perceived a high capacity to shift to other systems such as fish, integrated gardenpond-animal shed systems, and vegetables.

\section{DISCUSSION AND CONCLUSION}

\section{Factors that characterize resilience components of agricultural systems in the deltas}

\section{Sensitivity of agricultural systems to increased salinity}

The existence of protective infrastructure is a key factor shaping differences in resilience to salinity of farming systems between the two deltas, especially the sensitivity to increased salinity intrusion. In the RRD, the system of concrete sea dikes and sluice gates makes the entire area a freshwater zone. Agricultural systems generally have low exposure and sensitivity to salinity intrusion and high recovery capacity but have a low capacity to change to other systems. In the MKD, agricultural systems are more exposed to salinity because of a close connection between farming systems and the surrounding environment. Rice-shrimp and shrimp systems in the MKD are less sensitive to increased salinity intrusion thanks to the higher salt tolerance level of shrimp and an adaptation of rice and shrimp farming systems to seasonal fluctuation in salinity conditions.

Table 6. Median values of perceived capacity to change of agricultural systems by the interviewed farmers in the Red River Delta (interquartile ranges in parentheses). The values in the table represent a "1-5 Likert scale" standing for very little (1) to very much (5) ability. Significant difference of perceived capacity to change between farming systems $\left(\chi^{2}(5)=20.06, p=0.001\right.$; Kruskal-Wallis test). The median values with different superscripts are significantly different ( $\mathrm{p}<0.05$, Dunn's test).

\begin{tabular}{lcccccc}
\hline \hline & $\begin{array}{c}\text { Double } \\
\text { Rice }\end{array}$ & Vegetable & $\begin{array}{c}\text { Rice- } \\
\text { Vegetable }\end{array}$ & $\begin{array}{c}\text { Fish } \\
\text { Pond }\end{array}$ & $\begin{array}{c}\text { Soft- } \\
\text { Shell } \\
\text { Turtle }\end{array}$ & $\begin{array}{c}\text { Large } \\
\text { Fish } \\
\text { Pond }\end{array}$ \\
\hline $\begin{array}{l}\text { Perceived } \\
\begin{array}{l}\text { capacity to } \\
\text { change }\end{array}\end{array}$ & $\begin{array}{c}3.0^{\mathrm{a}} \\
(2.0-4.0)\end{array}$ & $\begin{array}{c}4.5^{\mathrm{b}} \\
(4.0-5.0)\end{array}$ & $\begin{array}{c}4.0 \\
(3.0-5.0)\end{array}$ & $\begin{array}{c}2.5^{\mathrm{a}} \\
(2.0-4.0)\end{array}$ & $\begin{array}{c}4.0 \\
(3.0-5.0)\end{array}$ & $\begin{array}{c}2.0^{\mathrm{a}} \\
(2.0-4.0)\end{array}$ \\
\hline
\end{tabular}

In both deltas, the uptake of salt-tolerant rice varieties is a factor lowering the sensitivity of the system to salinity (Table 7). There is some evidence that at a salinity threshold below $3 \mathrm{ppt}$, rice production in the MKD would be maintained if sensitive rice varieties were replaced by salt-tolerant rice varieties (Smajgl et al. 2015). In the MKD, an early seasonal occurrence of salinity intrusion can significantly affect the rice crop. Thus, rice farmers have attempted to shorten the rice growing cycle, e.g., by adopting short-cycle rice varieties and transplanted rice, to harvest the rice crop before the onset of saline conditions. To improve their performance, these agronomic measures are usually applied together with additional strategies such as adjustment in cropping calendar, agrochemical application and soil preparation, and irrigation management (Nhan et al. 2012).

Another factor that can influence the sensitivity and coping capacity of farming systems to salinity intrusion is the use and communication of salinity measurements or information by farmers. In the MKD, rice-shrimp and shrimp farmers generally use salinity information for their farming activities more often 
Table 7. Factors that characterize the resilience components of agricultural systems. MKD, Mekong Delta; RRD, Red River Delta.

\begin{tabular}{|c|c|c|c|c|c|}
\hline & Rice (MKD) & Rice-Shrimp (MKD) & Shrimp (MKD) & Rice (RRD) & $\begin{array}{l}\text { Rice-Vegetable, Vegetable, Fish } \\
\text { Pond, Soft-Shell Turtle, and Large } \\
\text { Fish Pond Systems (RRD) }\end{array}$ \\
\hline \multirow[t]{3}{*}{$\begin{array}{l}\text { Factors that increase/ } \\
\text { decrease the sensitivity } \\
\text { to increased salinity }\end{array}$} & $\begin{array}{l}\text { Low salt- } \\
\text { tolerance level of } \\
\text { rice varieties } \\
\text { (increase) }\end{array}$ & $\begin{array}{l}\text { Application of salt- } \\
\text { tolerant rice varieties } \\
\text { (decrease) }\end{array}$ & $\begin{array}{l}\text { High salt-tolerance } \\
\text { level of shrimp } \\
\text { (decrease) }\end{array}$ & $\begin{array}{l}\text { Low salt-tolerance } \\
\text { level of rice varieties } \\
\text { (increase) }\end{array}$ & $\begin{array}{l}\text { High salt-tolerance levels of } \\
\text { vegetable crops, fish, and soft-shell } \\
\text { turtles (decrease) }\end{array}$ \\
\hline & $\begin{array}{l}\text { Salinity damage } \\
\text { during the } \\
\text { sensitive time for } \\
\text { the rice crop } \\
\text { (increase) }\end{array}$ & $\begin{array}{l}\text { Regular use of salinity } \\
\text { information (decrease) }\end{array}$ & $\begin{array}{l}\text { Low exposure to the } \\
\text { river waters by water } \\
\text { recycling (decrease) }\end{array}$ & $\begin{array}{l}\text { Management of } \\
\text { sluice gate operation } \\
\text { and water intake } \\
\text { (decrease) }\end{array}$ & $\begin{array}{l}\text { Less regular exchange with the } \\
\text { river waters (decrease) }\end{array}$ \\
\hline & $\begin{array}{l}\text { Limited use of } \\
\text { salinity } \\
\text { information } \\
\text { (increase) }\end{array}$ & & $\begin{array}{l}\text { Regular use of salinity } \\
\text { information (decrease) }\end{array}$ & & \\
\hline \multirow[t]{4}{*}{$\begin{array}{l}\text { Factors that increase/ } \\
\text { decrease the capacity } \\
\text { to recover }\end{array}$} & $\begin{array}{l}\text { High support } \\
\text { from the } \\
\text { government and } \\
\text { neighbors } \\
\text { (increase) }\end{array}$ & $\begin{array}{l}\text { Availability of } \\
\text { freshwater supplies for } \\
\text { leaching salinity after } \\
\text { salinity damage } \\
\text { (increase) }\end{array}$ & $\begin{array}{l}\text { High investment } \\
\text { capital requirement } \\
\text { (decrease) }\end{array}$ & $\begin{array}{l}\text { Availability of } \\
\text { irrigation water for } \\
\text { washing salinity } \\
\text { (increase) }\end{array}$ & $\begin{array}{l}\text { Availability of investment capital } \\
\text { for an increase of input use (e.g., } \\
\text { fertilizer) (increase) }\end{array}$ \\
\hline & $\begin{array}{l}\text { High access to } \\
\text { loans (increase) }\end{array}$ & $\begin{array}{l}\text { High investment capital } \\
\text { requirement (decrease) }\end{array}$ & $\begin{array}{l}\text { High access to loans } \\
\text { (increase) }\end{array}$ & $\begin{array}{l}\text { Availability of } \\
\text { investment capital } \\
\text { for an increase of } \\
\text { input use (e.g., } \\
\text { fertilizer) (increase) }\end{array}$ & $\begin{array}{l}\text { High loans and subsidies for } \\
\text { vegetable production (increase) }\end{array}$ \\
\hline & $\begin{array}{l}\text { High off-farm } \\
\text { income (increase) }\end{array}$ & $\begin{array}{l}\text { Low access to loans } \\
\text { (decrease) } \\
\text { Low off-farm income } \\
\text { (decrease) }\end{array}$ & $\begin{array}{l}\text { High off-farm income } \\
\text { (increase) } \\
\text { High support from the } \\
\text { government and } \\
\text { neighbors (increase) }\end{array}$ & $\begin{array}{l}\text { High neighbor help } \\
\text { (increase) } \\
\text { Low access to loans } \\
\text { and subsidies } \\
\text { (decrease) }\end{array}$ & High neighbor help (increase) \\
\hline & & $\begin{array}{l}\text { Low support from the } \\
\text { government and } \\
\text { neighbors (decrease) }\end{array}$ & & & \\
\hline \multirow[t]{2}{*}{$\begin{array}{l}\text { Factors that decrease } \\
\text { the capacity to change }\end{array}$} & $\begin{array}{l}\text { Inflexible } \\
\text { regulatory } \\
\text { framework for } \\
\text { change }\end{array}$ & $\begin{array}{l}\text { Land modification. Too } \\
\text { deep excavation of the } \\
\text { fields for shrimp } \\
\text { farming causes } \\
\text { difficulty for rice } \\
\text { cultivation in the wet } \\
\text { season and locks in the } \\
\text { system to shrimp } \\
\text { production. }\end{array}$ & Soil salinization & $\begin{array}{l}\text { Inflexible regulatory } \\
\text { framework for } \\
\text { change }\end{array}$ & $\begin{array}{l}\text { Investment capital requirement to } \\
\text { fill the land (for fish and soft-shell } \\
\text { turtles) }\end{array}$ \\
\hline & & & $\begin{array}{l}\text { Difficulty of reversion } \\
\text { of the modified } \\
\text { landform from shrimp } \\
\text { ponds to other systems }\end{array}$ & & \\
\hline
\end{tabular}

than rice farmers and therefore can react more quickly when salinity levels start rising. In the semistructured interviews, rice farmers mentioned that they received information on salinity from television, rice-shrimp farmers, and from the operators of pumping stations or sluice gates. In the brackish water zone, a majority of rice-shrimp farmers, e.g., 7 out of 11 farmers in Kien Giang and 8 out of 12 farmers in Soc Trang, measured the salinity, whereas others received information from other rice-shrimp farmers, shrimp stock sellers, and television. In the saline water zone in both provinces, most farmers measured the salinity levels before pumping the water into the ponds. This salinity information, however, was acquired only when the saline water had already entered the canals. In the RRD, salinity monitoring and operation of sluice gates and pumping stations, which are managed by a state irrigation company, are also important factors for preventing salinity damage. Monitoring and long-term projections of salinity levels would build resilience in all agricultural systems in both deltas by enhancing their adaptive capacity to confront changes and increase the preparedness of farmers facing increased salinity intrusion (Adger et al. 2005, Renaud et al. 2015).

Capacity of agricultural systems to recover after salinity damage Financial capital is an important factor contributing to the capacity to recover from salinity damage of many farming systems in the deltas. For rice-shrimp and shrimp systems in the MKD, the recovery is largely based on capital investment because the investment for rice-shrimp and shrimp cultivation is much higher than for the double rice system (Joffre et al. 2010, Thuy and Ford 
2010, Can 2016). In the semistructured interviews, farmers mentioned that they usually harvest their shrimp immediately if they experience evidence of failure to partially regain the invested capital. This can be done for 2- to 2.5-month-old black tiger shrimp and 1- to 1.5-month-old white leg shrimp. This capital is therefore important for the investment in the next season. In the $\mathrm{RRD}$, investment capital is usually required for increasing input uses to recover from the salinity damage.

In the RRD, most farmers perceived that their farming systems can recover easily. This high ranking of the recovery capacity of agricultural systems in the RRD, however, might be influenced by farmers' perceptions of mild salinity intrusion episodes as experienced in the past, when farmers could easily flush out salinity from rice fields and increase the use of inputs to compensate for the damage to rice, fish, and soft-shell turtle production (Dat et al. 2014). Thus, the perceived capacity to recover of these systems would be lower if salinity intrusion increases, and such coping measures will no longer be effective for a full recovery of the systems following salinity damage.

Support from other farmers and the government is another factor that enhances the recovery capacity of agricultural systems, especially during times of crisis. At present, the government has policies to promote double rice production, and rice farmers can receive a subsidy of 50,000 Vietnamese dong (approximately US\$2.5) per 0.1 ha in case of salinity damage (Government of Vietnam 2012). In the structured interviews in the MKD, rice and shrimp farmers have reported a higher probability of receiving help from other farmers and the government, whereas rice-shrimp farmers reported a lower ability to receive this kind of support (see Appendix 1). In all villages in the RRD, farmers mentioned receiving high levels of support from other farmers, e.g., loans and direct help, and except for vegetable production, farmers reported low government support, e.g., subsidies and loans (see Appendix 2). One explanation for low perceived government support in the RRD is that farms are typically smaller (Tuan 2010), limiting the accessibility of subsidies and loans for farmers.

Capacity of agricultural systems to change to other systems At present, the rice system in both deltas is locked in by the "rice first" policy that favors rice production and discourages shifting to alternative systems (Government of Vietnam 2012). This comes hand in hand with the development of infrastructure built to limit salinity intrusion and boost irrigation capacity, infrastructure that then requires a return on investment, thus also contributing to the lock-in effect. Another constraining factor regarding the capacity to change is linked to the biophysical characteristics of the land/pond. In the MKD, soil salinization and land modification from practicing shrimp farming and rice-intensive shrimp systems in Soc Trang (Table 7) need technical solutions to remedy and investments to refill the ponds. These are the main factors preventing the reversion and change to other systems of shrimp and rice-intensive shrimp systems (Thuy and Ford 2010). Investment capital to fill the pond is also a barrier to reverse or to shift to other systems for fish and soft-shell turtle systems in the RRD.

\section{Resilience trade-offs in agricultural shifts and navigation of resilience components in the context of increased salinity intrusion}

The assessment of resilience according to the criteria of the sensitivity of agricultural systems to increased salinity intrusion and capacities to recover and change resulted in none of the agricultural systems being ranked first in all resilience components. This finding implies that a shift from one system to another to reduce the sensitivity or improve the capacity to recover or change would affect other resilience components negatively. For example, a change from double rice to rice-shrimp would reduce the sensitivity to salinity intrusion and increase the capacity to change but decrease the recovery capacity of the system. Similarly, a change from rice-shrimp to shrimp can reduce the sensitivity and increase the capacity to recover but decrease the capacity to change in the future (Fig. 3). Similarly, a shift from double rice to fish in the RRD can limit the sensitivity to salinity intrusion. However, this comes at the expense of capacities to recover and to change to other systems when necessary.

There have been many discussions about the resilience trade-offs involved in the transformation of livelihoods, as adaptation and change may impoverish people and reinforce systems in undesirable states, as well as negatively affect resilience in other places because of cross-scale interactions (Chelleri et al. 2015, Tanner et al. 2015). The relative importance of the three resilience components and the allocation of resources for their improvement are dependent on the changing salinity conditions and whether the systems are undergoing gradual or abrupt changes (Darnhofer 2014). The management practices therefore need to balance between the implementation of incremental adaptation to reduce the sensitivity and increase the recovery capacity of agricultural systems, and the selection of transformative adaptation to change and transform into a new system when fundamental changes are required (Bennett et al. 2014, Darnhofer 2014).

\section{Agricultural management for reducing sensitivity to salinity intrusion}

Under a specific salinity level, agricultural systems can buffer salinity without changing their structures and feedbacks (Darnhofer 2014). The implementation of adaptive farming technologies such as salt-tolerant rice varieties, adjustment of the cropping calendar, or control of irrigation and water intake would be effective to prevent salinity damage on rice and rice-shrimp systems (Table 7; Nhan et al. 2012, Renaud et al. 2015). Additional solutions could be the development of early warning systems and awareness raising on salinity intrusion to reduce the exposure of the systems to high-salinity events. Structural adaptation measures such as the construction of protective infrastructures and improvement of irrigation networks, as well as the application of ecosystem-based adaptation measures such as mangrove reforestation and wetland rehabilitation, could also limit the magnitude of salinity intrusion (Renaud et al. 2015, Smajgl et al. 2015). One of the risks of structural measures is the modification of the hazard exposure and the focus on one resilience component that may degrade other resilience components and the overall resilience in the longer run because of a decline of biodiversity, functional redundancy, and spatial variation (Adger et al. 2005, Biggs et al. 2012).

Agricultural management for enhancing recovery capacity after salinity damage

An alternative solution is to improve the recovery capacity to keep the systems in place and quickly recover from salinity damage. For instance, the diversification of income sources would be one such measure. In the MKD, farmers in the freshwater zone have 
Fig. 3. Resilience and changes in resilience factors by shifting agricultural systems in the Mekong Delta (the bigger the propeller, the higher the sensitivity, recovery, or ability to change of agricultural systems). The shift from one system to another will help to reduce the sensitivity of the system to salinity intrusion (a), increase the capacity to recover (b), or improve the capacity to change (c). These shifts consequently increase the sensitivity ( $b$ and $c$ : from shrimp to double rice), reduce the capacity to recover ( $a$ and $c$ : from double rice to rice-shrimp), or degrade the capacity to change (a: from double rice to rice-shrimp; $b$ : from rice-shrimp to shrimp). The red blocks indicate shifts that are either very difficult or not currently possible.

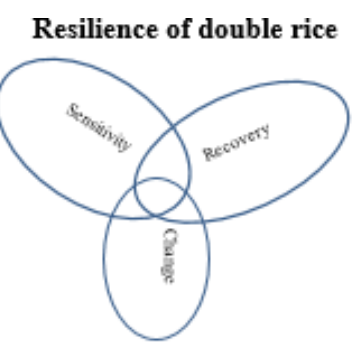

Double rice

\section{Resilience of rice-shrimp}

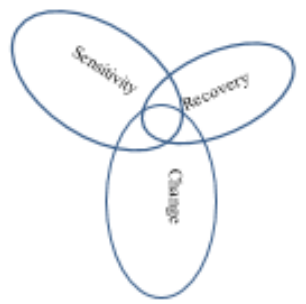

Rice-shrimp

\section{Resilience of shrimp}

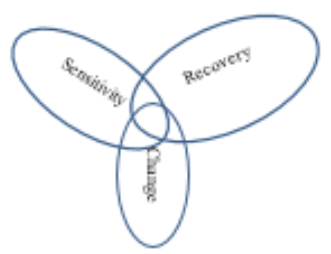

Shrimp

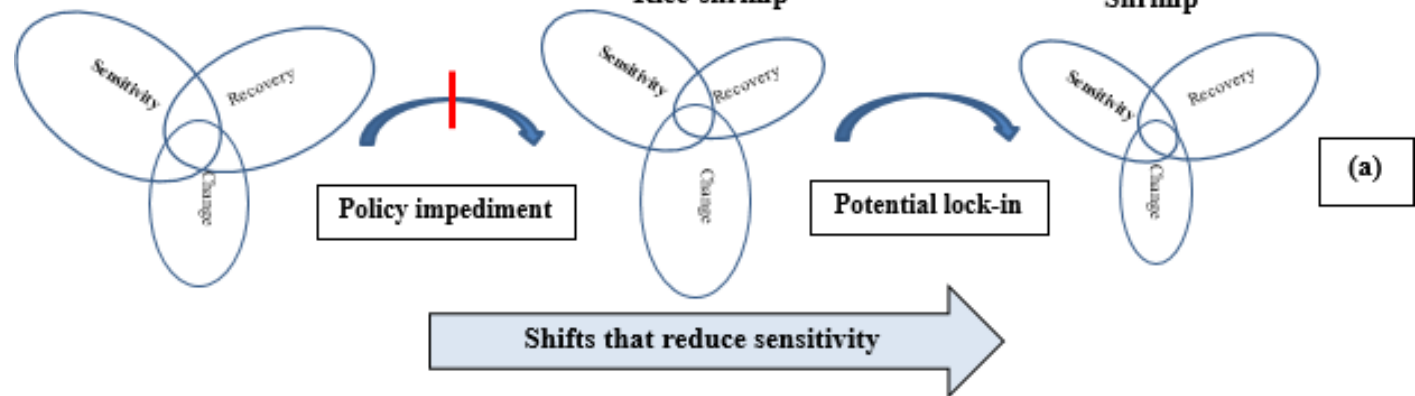

Rice-shrimp

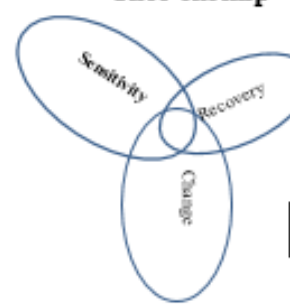

Potential lock-in

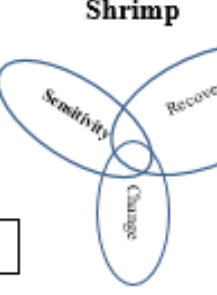

rimp

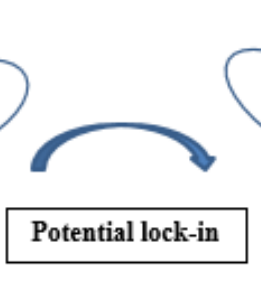

Shifts that enhance capacity to recovery

\section{y}

Shrimp

Double rice
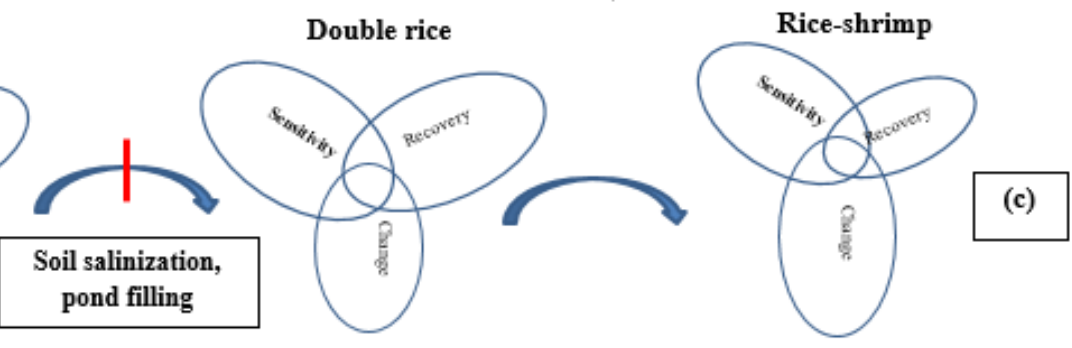

Shifts that improve capacity to change

integrated double rice with vegetables, whereas farmers in the brackish and saline water zones have diversified rice-shrimp and shrimp systems with livestock to buffer yield losses. Additional measures could be considered at higher levels beyond farm management such as subsidization for salinity damages, crop insurance to pool risk, and generation of off-farm income. Since Doi Moi in 1986, the economic structure and livelihoods of farming households in both deltas have altered fundamentally 
toward diversification of income sources, with an increase in the share of income from wage and nonfarm activities and a decline of on-farm income (Tuan 2010, Garschagen et al. 2012, Ha 2016). At the national level, the shares of the agricultural sector in the economy have declined continuously from about $38.1 \%$ in 1986 to about $16.0 \%$ in 2016 (GSO 2017). Agricultural laborers in the deltas have increasingly migrated to the big cities to work in the industrial and service sectors (Anh et al. 2003, Tuan 2010, Garschagen et al. 2012). In the research areas of the RRD, many interviewed households have off-farm income and receive remittances from family members in addition to the on-farm income. In all villages, about $39 \%$ of households had at least one member who permanently migrated out of the district, and about $52 \%$ of households had off-farm jobs such as making handicrafts, fishing, and operating small-scale businesses. In the MKD, about $29 \%$ of households responding to the semistructured interviews had at least one member permanently migrating out of the district, and about $33 \%$ of households had off-farm income. This could be considered as contributing adaptation measures to salinity intrusion and other natural hazards that influence the resilience of the farming systems in the research areas (Adger et al. 2002, Dun 2011, Dat et al. 2014), even if they were initially put in place for boosting income and livelihoods.

These incremental adaptations for buffering the consequences and enhancing the recovery capacity from salinity damage do not necessarily change the qualitative state of the system (IPCC 2014, Schwab et al. 2016). If higher salinity levels materialize in the long term, these measures may not be effective at helping the system to fully recover from damages (Binh 2015). The increased external pressures, in particular salinity intrusion and the changing internal agricultural structures and feedbacks, will slowly push the agricultural systems over a threshold toward undesirable states (Bennett et al. 2014, Müller et al. 2014). The change of system states in this case does not necessarily take place after the salinity level has reached its threshold, but even earlier than this point after the household's adaptive capacity for adaptation to salinity has been degraded. This could result in falling into a poverty trap in a system increasingly threatened by salinity intrusion, with undermined social-economic capital for adaptation (Binh 2015).

\section{Agricultural management for improving capacity to change}

Another option would be the shift to new systems with lower sensitivity to salinity intrusion or higher recovery capacity from salinity damage before severe impacts are felt (see Fig. 2). During the interviews in the saline water zone in Kien Giang, shrimp farmers mentioned the discontinuity of income from monthly shrimp harvesting during the rice season in cases where they reverted to rice-shrimp production. In the RRD, many farmers wish to change their double rice systems to aquaculture if policies allowed them to do so. These agricultural transformations may be disruptive and thus require the introduction of a flexible regulatory framework for changes and outside supports, e.g., loans and training, for trying and learning new farming practices and systems. The shift from one system to another, for instance, from double rice to fish pond and soft-shell turtle systems in the RRD, would also degrade other resilience components, in particular the capacities to recover and to change. A shift from rice-shrimp to shrimp in the brackish water zone in the MKD would lock in the system to shrimp production, constraining further shifts to other systems (Tho et al. 2008, Thuy and Ford
2010). In the face of changing social-ecological conditions in the deltas that will pose more opportunities and challenges, the shifts that allow the reversion or transformation to other systems to address future developments should be favored as opposed to shifts that may lock in agricultural systems to path dependencies and hinder future changes (Renaud et al. 2015). Some integrated farming systems such as single or double rice combined with vegetable, coconut, or rice-extensive aquaculture in the MKD, and integrated rice-garden-animal shed systems or rice-vegetable in the RRD, would diversify farmers' income sources, which could contribute to buffer salinity-induced damages and create opportunities for further innovation. The conversion to these systems does not require substantial land modification and thus would keep the natural capital and future options relatively intact and also be accepted to some extent by the government.

\section{Limitations and insights from subjective assessment of resilience}

There are some limitations in our subjective assessment of resilience. The first bias could be linked to the framing of the questions by researchers and the way respondents perceived them. In this regard, there might be discrepancies in farmers' perceptions of different components of resilience. For example, in the assessment of the capacity to recover from salinity damage, rice-shrimp farmers could think about recovery in the next season, whereas rice farmers might refer to recovery within the same season. This difference in farmers' perceptions is also relevant for the assessment of the sensitivity of agricultural systems because farmers may think of different salinity levels depending on their past experiences. We have defined the resilience components generally, and the measurement is based on a single question for each component. The strengths and weaknesses of using a general and single question compared with the use of a more specific set of questions have been well discussed in Jones and Tanner (2017). The generalizability of questions allowed us to apply them across a wider range of contexts. However, a more detailed definition of each resilience component could be considered to reduce the variation, for example, by applying a set of general statements on income or production amount for each component such as in the study by Kien and James (2013). These general statements, however, should be derived from farmers' perspectives and have equal meaning and importance in all research areas. A second potential drawback is the fact that marginal groups might give a higher value on the Likert scale than they actually feel (Jones and Samman 2016), or deviations in cultural norms between different ethnic groups (e.g., Kinh and Khmer), regions (e.g., between the Mekong and Red River deltas), or gender might influence the answers from respondents. The careful design and pretesting of the elicited questions has been suggested for the subjective measurement of resilience to limit both the researchers and respondents' biases (Clare et al. 2017, Jones and Tanner 2017). We carried out an extensive questionnaire pretest and the application of both the scoring and the explanation for the selection to reduce these biases.

In addition, agricultural systems in the deltas are currently exposed to multiple social and environmental stressors from water-related hazards, social-economic transitions, and market volatility (Cong et al. 2009, de Araujo Barbosa et al. 2016). Responses of agricultural systems to these stressors would influence the resilience of the systems to salinity intrusion and other stressors in different dimensions. For instance, increased 
migration and remittances could contribute to lifting the migrantsending households out of poverty (Duc et al. 2015) and thus boost their capacity to recover from salinity damage and provide investment capital for shifting to new systems. However, a move of the prime labor force, e.g., young and highly educated people, would lead to a lack of productive labor force for agricultural activities and climate change adaptation (Anh 1998). Although the study aimed to assess the resilience of farming systems to salinity intrusion as a specific environmental stressor, other multiple shocks and trends within and beyond the delta level could influence the general resilience of these systems. Thus, a system highly resilient to salinity would be less resilient to other stressors, for example a market fluctuation or an epidemic. A specified resilience assessment as we presented therefore would limit the social-ecological understanding of resilience as the ability of systems to transform to alternative system states to deal with new and unpredictable stressors (Nelson et al. 2007, Chelleri et al. 2015, O’Connell et al. 2015).

Similar to the study of Jones and Samman (2016), we did not find a strong association of household characteristics such as wealth, education, age of household heads, and group membership on subjective resilience-related components (see Appendix 3). There were also no significant differences between farming systems in the MKD with relation to households' perceived sensitivity of their systems to increased salinity intrusion and perceived capacity to change. There are some explanations and implications of this result: (1) The application of subjective resilience assessment using a single question for each component was not enough to capture the resilience of agricultural systems. To date, there has not been a standard resilience approach to validate the resilience assessment and measurement and to compare between subjective and objective measurements of resilience (Clare et al. 2017). In this regard, complementing subjective resilience assessment with qualitative data, e.g., from FGDs and in-depth interviews, provides a more holistic understanding of resilience and its determinants. (2) The socioeconomic characteristics of households were not important in determining the subjective resilience of farmers. Therefore, we may need to include more variables related to the ecological component of the farming system such as soil or irrigation characteristics to test for the associations. (3) The application of the 5-point Likert scale may not yield comparable results of resilience because farmers are limited in terms of responses. An application of more evaluation scales, e.g., 7-point Likert scales or higher, in the elicited questions, such as in Clare et al. (2017), therefore could be considered. In addition, supplementing qualitative information from FGDs and in-depth interviews could offer insights into resilience and would allow for a comparison of resilience between agricultural systems and communities. We found that the qualitative information was useful to explore the drivers of resilience as well as to explain potential differences in resilience components between farming systems. This enabled the identification or confirmation of the differences in resilience components where the statistical analysis was not applicable or was not able to reveal significant differences between systems.

Responses to this article can be read online at: http://www.ecologyandsociety.org/issues/responses. php/11186

\section{Acknowledgments:}

The research was funded by the Federal Ministry of Education and Research (BMBF), Germany, through the "Sustainable adaptation of coastal agro-ecosystems to increased salinity intrusion" (DeltAdapt) project in Vietnam. The authors would like to thank Dr. Michael Hagenlocher (UNU-EHS) and Dr. Maria Schwab (Europa-Universität Flensburg) for their insightful comments on previous drafts of this paper, and Dr. Ngo The An and Ms. Tran Thanh Van (Vietnam National University of Agriculture) for their support during the field research.

\section{LITERATURE CITED}

Adger, W. N., T. P. Hughes, C. Folke, S. R. Carpenter, and J. Rockström. 2005. Social-ecological resilience to coastal disasters. Science 309(5737):1036-1039. https://doi.org/10.1126/science.1112122

Adger, W. N., P. M. Kelly, A. Winkels, L. Q. Huy, and C. Locke. 2002. Migration, remittances, livelihood trajectories, and social resilience. AMBIO: A Journal of the Human Environment 31 (4):358-366. https://doi.org/10.1579/0044-7447-31.4.358

Aizawa, M., N. D. Can, N. V. Hao, H. Kurokura, and K. Kobayashi. 2009. Changes in rice farmers' agronomic practices in response to changes in hydrological conditions for salinity prevention in the Mekong Delta, Vietnam. Japanese Journal of Tropical Agriculture 53(2):33-42. https://doi.org/10.11248/ jsta. 53.33

Alexander, D. E. 2013. Resilience and disaster risk reduction: an etymological journey. Natural Hazards and Earth System Sciences 13(11):2707-2716. https://doi.org/10.5194/nhess-13-2707-2013

Anh, H. T. K. 1998. Spontaneous rural to urban migration and its link to rural development in Vietnam. Thesis. Saint Mary's University, Halifax, Nova Scotia, Canada.

Anh, N. N. 2017. Lessons learned and response solutions. Vietnam Journal of Science and Technology 1(1):2015-2018.

Anh, D. N., T. Cecilia, and H. X. Thanh. 2003. Migration in Vietnam - a review of information on current trends and patterns, and their policy implications. Page 283-325 in Regional conference on migration, development and pro-poor policy choices in Asia (Dhaka, Bangladesh, 2003). Department for International Development, London, UK; Refugee and Migratory Movements Research Unit, University of Dhaka, Dhaka, Bangladesh.

Asch, F., and M. C. S. Wopereis. 2001. Responses of field-grown irrigated rice cultivars to varying levels of floodwater salinity in a semi-arid environment. Field Crops Research 70:127-137. https://doi.org/10.1016/S0378-4290(01)00128-9

Beauchamp, E., J. Abdella, S. Fisher, J. McPeak, H. Patnaik, P. Koulibaly, D. Cissé, M. Touré, A. Bocoum, M. Ndao, Y. Deme, and B. Gueye. 2019. Resilience from the ground up: how are local resilience perceptions and global frameworks aligned? Disasters 43(S3):S295-S317. https://doi.org/10.1111/disa.12342

Béné, C. 2013. Towards a quantifiable measure of resilience. IDS Working Papers 2013(434):1-27. https://doi.org/10.1111/ j.2040-0209.2013.00434.X

Béné, C., T. Frankenberger, M. Langworthy, M. Mueller, and S. Martin. 2016. The influence of subjective and psycho-social factors 
on people's resilience: conceptual framework and empirical evidence. Technical Report Series No. 2. Livestock Research Institute and TANGO International, Nairobi, Kenya.

Bennett, E., S. Carpenter, L. Gordon, N. Ramankutty, P. Balvanera, B. Campbell, W. Cramer, J. Foley, C. Folke, L. Karlberg, J. Liu, H. Lotze-Campen, N. Mueller, G. Peterson, S. Polasky, J. Rockström, R. Scholes, and M. Spierenburg. 2014. Toward a more resilient agriculture. Solutions Journal 5(5):65-75.

Berkes, F., and C. S. Seixas. 2005. Building resilience in lagoon social-ecological systems: a local-level perspective. Ecosystems 8 (8):967-974. https://doi.org/10.1007/s10021-005-0140-4

Bernard, R. H. 2000. Social research methods: qualitative and quantitative approaches. Sage, London, UK.

Biggs, R., M. Schlüter, D. Biggs, E. L. Bohensky, S. BurnSilver, G. Cundill, V. Dakos, T. M. Daw, L. S. Evans, K. Kotschy, A. M. Leitch, C. Meek, A. Quinlan, C. Raudsepp-Hearne, M. D. Robards, M. L. Schoon, L. Schultz, and P. C. West. 2012. Toward principles for enhancing the resilience of ecosystem services. Annual Review of Environment and Resources 37:421-448. https:// doi.org/10.1146/annurev-environ-051211-123836

Binh, N. T. 2015. Vulnerability and adaptation to salinity intrusion in the Mekong Delta of Vietnam. Dissertation. University of Bonn, Bonn, Germany.

Briggs, M., S. Funge-Smith, R. Subasinghe, and M. Phillips. 2004. Introductions and movement of Penaeus vannamei and Penaeus stylirostris in Asia and the Pacific. FAO Regional Office for Asia and the Pacific, Bangkok, Thailand.

Can, N. D. 2016. Adaptation to salinity intrusion: an economic assessment of diversified farming systems in saline affected area of coastal Ben Tre Province of the Mekong Delta, Vietnam. Pages 15-26 in International symposium on current agricultural environmental issues in Pacific Rim nations and their countermeasures - II (Saga, Japan, 2015). Saga University, Saga Japan; United Graduate School of Agricultural Sciences, Kagoshima University, Kagoshima, Japan.

Carew-Reid, J. 2008. Rapid assessment of the extent and impact of sea level rise in Viet Nam. Climate Change Discussion Paper 1. International Centre for Environmental Management, Brisbane, Queensland, Australia.

Carpenter, S., B. Walker, J. M. Anderies, and N. Abel. 2001. From metaphor to measurement: resilience of what to what? Ecosystems 4(8):765-781. https://doi.org/10.1007/s10021-001-0045-9

Carpenter, S. R., F. Westley, and M. G. Turner. 2005. Surrogates for resilience of social-ecological systems. Ecosystems 8 (8):941-944. https://doi.org/10.1007/s10021-005-0170-y

CGIAR Research Program on Climate Change, Agriculture and Food Security-Southeast Asia (CCAFS-SEA). 2016. The drought and salinity intrusion in the Mekong River Delta of Vietnam: assessment report. CCAFS-SEA Regional Program, Hanoi, Vietnam.

Chelleri, L., J. J. Waters, M. Olazabal, and G. Minucci. 2015. Resilience trade-offs: addressing multiple scales and temporal aspects of urban resilience. Environment and Urbanization 27 (1):181-198. https://doi.org/10.1177/0956247814550780
Ciani, F., and D. Romano. 2014. Testing for household resilience to food insecurity: evidence from Nicaragua. In 2014 Third Congress (Alghero, Italy, 25-27 June 2014). Italian Association of Agricultural and Applied Economics, Alghero, Italy. http://dx. doi.org/10.22004/ag.econ.172958

Clare, A., R. Graber, L. Jones, and D. Conway. 2017. Subjective measures of climate resilience: what is the added value for policy and programming? Global Environmental Change 46:17-22. https://doi.org/10.1016/j.gloenvcha.2017.07.001

Cong, M. V., M. J. F. Stive, and P. H. A. J. M. Van Gelder. 2009. Coastal protection strategies for the Red River Delta. Journal of Coastal Research 2009(251):105-116. https://doi.org/10.2112/07-0888.1

Cumming, G. S., G. Barnes, S. Perz, M. Schmink, K. E. Sieving, J. Southworth, M. Binford, R. D. Holt, C. Stickler, and T. Van Holt. 2005. An exploratory framework for the empirical measurement of resilience. Ecosystems 8(8):975-987. https://doi. org/10.1007/s10021-005-0129-Z

Darnhofer, I. 2014. Resilience and why it matters for farm management. European Review of Agricultural Economics 41 (3):461-484. https://doi.org/10.1093/erae/jbu012

Dat, T. Q., K. Likitdecharote, T. Srisatit, and N. H. Trung. 2011. Modeling the influence of river discharge and sea level rise on salinity intrusion in Mekong Delta. Pages 685-701 in First Environment Asia International Conference on "Environmental Supporting in Food and Energy Security: Crisis and Opportunity" (Bangkok, Thailand, 2011). Thai Society of Higher Education Institutes on Environment, Bangkok, Thailand.

Dat, T. T., V. Thi, H. Thu, and P. N. Toan. 2014. Vulnerability and adaptation of coastal livelihoods to the impacts of climate change: a case study in coastal districts of Nam Dinh, Vietnam. Journal of Economics and Development 16(2):39-60.

de Araujo Barbosa, C. C., J. Dearing, S. Szabo, S. Hossain, N. T. Binh, D. K. Nhan, and Z. Matthews. 2016. Evolutionary social and biogeophysical changes in the Amazon, GangesBrahmaputra-Meghna and Mekong deltas. Sustainability Science 11(4):555-574. https://doi.org/10.1007/s11625-016-0371-7

d'Errico, M., F. Grazioli, and R. Pietrelli. 2018. Cross-country evidence of the relationship between resilience and the subjective perception of well-being and social inclusion: evidence from the regions of Matam (Senegal) and the Triangle of Hope (Mauritania). Journal of International Development 30 (8):1339-1368. https://doi.org/10.1002/jid.3335

Dinno, A. 2015. Nonparametric pairwise multiple comparisons in independent groups using Dunn's test. Stata Journal 15 (1):292-300. https://doi.org/10.1177/1536867X1501500117

Duc, N. L., K. Raabe, and U. Grote. 2015. Rural-urban migration, household vulnerability, and welfare in Vietnam. World Development 71:79-93. https://doi.org/10.1016/j. worlddev.2013.11.002

Dun, O. 2011. Migration and displacement triggered by floods in the Mekong Delta. International Migration 49(S1):e200-e223. https://doi.org/10.1111/j.1468-2435.2010.00646.x

Folke, C. 2016. Resilience (republished). Ecology and Society 21 (4):44. https://doi.org/10.5751/ES-09088-210444 
Food and Agriculture Organization of the United Nations (FAO). 2002. Agricultural drainage water management in arid and semiarid areas. FAO, Rome, Italy.

Food and Agriculture Organization of the United Nations (FAO). 2014. RIMA-II: Resilience Index Masurement and Analysis model. FAO, Rome, Italy.

Food Security Information Network (FSIN). 2014. Resilience measurement principles: toward an agenda for measurement design. Technical Series No. 1. Food Security Information Network, Rome Italy.

Frankenberger, T., M. Mueller, T. Spangler, and S. Alexander. 2013. Community resilience: conceptual framework and measurement Feed the Future learning agenda. Westat, Rockville, Maryland, USA.

Frankenberger, T., and S. Nelson. 2013. Summary of the expert consultation on resilience measurement for food security. Food Security Information Network, Rome, Italy.

Garschagen, M., J. R. Diez, D. K. Nhan, and F. Kraas. 2012. Socio-economic development in the Mekong Delta: between the prospects for progress and the realms of reality. Pages 83-132 in F. G. Renaud and C. Kuenzer, editors. The Mekong Delta system - interdisciplinary analyses of a river delta. Springer, Dordrecht, the Netherlands. https://doi.org/10.1007/978-94-007-3962-8 4

Government of Vietnam. 2000. Resolution on orientations and policies on economic restructuring and consumption of agricultural products. Resolution No. 09/2000/NQ-CP. Government of Vietnam, Hanoi, Vietnam.

Government of Vietnam. 2012. Decision on rice land management and use. Decision No. 42/2012/NĐ-CP. Government of Vietnam, Hanoi, Vietnam.

Government of Vietnam. 2016. Resolution on adjustment of plan use planning until 2020 and land use planning at the national level for the last period from 2016-2020. Resolution No. 134/2016/ QH13. Government of Vietnam, Hanoi, Vietnam.

General Statistics Office (GSO). 2015. Statistical yearbook of Vietnam. Statistical Publishing House, Hanoi, Vietnam.

General Statistics Office (GSO). 2017. Total national output according to economic sectors. Statistical Publishing House, Hanoi, Vietnam.

Ha, T. T. P. 2012. Resilience and livelihood dynamics of shrimp farmers and fishers in the Mekong Delta, Vietnam. Dissertation. Wageningen University, Wageningen, the Netherlands.

Ha, L. T. T. 2016. Study on the association of land use changes and demographics in Giao Thuy district, Nam Dinh province. Dissertation. Hanoi University of Mining and Geology, Hanoi, Vietnam.

Hai, P. V., and S.-I. Lee. 2015. Assessment of seawater intrusion potential from sea-level rise and groundwater extraction in a coastal aquifer. Desalination and Water Treatment 53 (9):2324-2338. https://doi.org/10.1080/19443994.2014.971617

Hashimoto, T. R. 2001. Environmental issues and recent infrastructure development in the Mekong Delta: review, analysis and recommendations with particular reference to large-scale water control projects and the development of coastal areas. Working Paper No. 4. Australian Mekong Resource Centre, University of Sydney, Sydney, Australia.

Hien, L. T., P. N. Quy, and N. T. Viet. 2010. Assessment of salinity intrusion in the Red River under the effect of climate change. Journal of Civil Engineering and Architecture 4(6):1-6.

IPCC. 2014. Summary for policymakers. Pages 1-32 in C. B. Field, V. R. Barros, D. J. Dokken, K. J. Mach, M. D. Mastrandrea, T. E. Bilir, M. Chatterjee, K. L. Ebi, Y. O. Estrada, R. C. Genova, B. Girma, E. S. Kissel, A. N. Levy, S. MacCracken, P. R. Mastrandrea, and L. L.White, editors. Climate change 2014: impacts, adaptation, and vulnerability. Part A: global and sectoral aspects. Contribution of Working Group II to the Fifth Assessment Report of the Intergovernmental Panel on Climate Change. Cambridge University Press, Cambridge, United Kingdom.

Joffre, O. 2015. Balancing options for shrimp farming: a landscape approach to investigate the future of shrimp farming in the Mekong Delta. Dissertation. Wageningen University, Wageningen, the Netherlands.

Joffre, O., M. Prein, P. B. V Tung, S. B. Saha, N. V Hao, and M. J. Alam. 2010. Evolution of shrimp aquaculture systems in the coastal zones of Bangladesh and Vietnam: a comparison. Pages 48-63 in C. T. Hoanh, B. W. Szuster, S.-P. Kam. A. M. Ismail, and A. E. Noble, editors. Tropical deltas and coastal zones: food production, communities and environment at the land-water interface. CABI, Oxforshire, UK.

Jones, L. 2019. Resilience isn't the same for all: comparing subjective and objective approaches to resilience measurement. Wiley Interdisciplinary Reviews: Climate Change 10(1):e552. https://doi.org/10.1002/wcc.552

Jones, L., and E. Samman. 2016. Measuring subjective household resilience insights from Tanzania. Overseas Development Institute, London, UK.

Jones, L., and T. Tanner. 2017. 'Subjective resilience': using perceptions to quantify household resilience to climate extremes and disasters. Regional Environmental Change 17(1):229-243. https://doi.org/10.1007/s10113-016-0995-2

Käkönen, M. 2008. Mekong Delta at the crossroads: more control or adaptation? AMBIO: A Journal of the Human Environment 37 (3):205-212. https://doi.org/10.1579/0044-7447(2008)37[205:MDATCM] 2.0. $\mathrm{CO} ; 2$

Kien, N. V., and H. James. 2013. Measuring household resilience to floods: a case study in the Vietnamese Mekong River Delta. Ecology and Society 18(3):13. https://doi.org/10.5751/ES-05427-180313

Kummu, M., and O. Varis. 2007. Sediment-related impacts due to upstream reservoir trapping, the Lower Mekong River. Geomorphology 85(3-4):275-293. https://doi.org/10.1016/j. geomorph.2006.03.024

Leigh, C., L. H. Hiep, B. Stewart-Koster, D. M. Vien, J. Condon, N. Van Sang, J. Sammut, and M. A. Burford. 2017. Concurrent rice-shrimp-crab farming systems in the Mekong Delta: are conditions (sub) optimal for crop production and survival? Aquaculture Research 48(10):5251-5262. https://doi.org/10.1111/ are. 13338 
Levine, S. 2014. Assessing resilience: why quantification misses the point. Humanitarian Policy Group Working Paper. Overseas Development Institute, London, UK.

Marschke, M. J., and F. Berkes. 2006. Exploring strategies that build livelihood resilience: a case from Cambodia. Ecology and Society 11(1):42. https://doi.org/10.5751/ES-01730-110142

Maxwell, D., M. Constas, T. Frankenberger, D. Klaus, and M. Mock. 2015. Qualitative data and subjective indicators for resilience measurement. Technical Series No. 4. Food Security Information Network, Rome, Italy.

Mekong River Commission (MRC). 2011. Assessment of basinwide development scenarios. MRC, Vientiane, Laos.

Ministry of Agriculture and Rural Development (MARD). 2013. Integrated information system-results-based monitoring \& evaluation on agricultural plan implementation. MARD, Hanoi, Vietnam.

Müller, D., Z. Sun, T. Vongvisouk, D. Pflugmacher, J. Xu, and O. Mertz. 2014. Regime shifts limit the predictability of land-system change. Global Environmental Change 28:75-83. https://doi. org/10.1016/j.gloenvcha.2014.06.003

Nelson, D. R., W. N. Adger, and K. Brown. 2007. Adaptation to environmental change: contributions of a resilience framework. Annual Review of Environment and Resources 32:395-419. https:// doi.org/10.1146/annurev.energy.32.051807.090348

Nhan, D. K., N. V. B. Be, and N. H. Trung. 2007. Water use and competition in the Mekong Delta, Vietnam. Pages 143-188 in T. T. Be, B. T. Sinh, and F. Miller, editors. Challenges to sustainable development in the Mekong Delta: regional and national policy issues and research needs. Sustainable Mekong Research Network, Bangkok, Thailand.

Nhan, D. K., V. A. Phap, T. H. Phuc, and N. H. Trung. 2012. Rice production response and technological measures to adapt to salinity intrusion in the coastal Mekong delta. Mekong Program on Water, Environment and Resilience. Can Tho University, Can Tho City, Vietnam.

O'Connell, D., B. Walker, N. Abel, and N. Grigg. 2015. The resilience, adaptation and transformation assessment framework: from theory to application. CSIRO, Canberra, Australian Capital Territory, Australia.

Overseas Development Institute (ODI). 2016. Analysis of resilience measurement frameworks and approaches. ODI, London, UK.

Pruszak, Z., P. Van Ninh, M. Szmytkiewicz, and N. M. Hung. 2005. Hydrology and morphology of two river mouth regions (temperate Vistula Delta and subtropical Red River Delta). Oceanologia 47(3):365-385.

Quinlan, A. E., M. Berbés-Blázquez, L. J. Haider, and G. D. Peterson. 2016. Measuring and assessing resilience: broadening understanding through multiple disciplinary perspectives. Journal of Applied Ecology 53(3):677-687. https://doi.org/10.1111/1365-$\underline{2664.12550}$

Renaud, F. G., and C. Kuenzer. 2012. Introduction. Pages 3-5 in F. G. Renaud and C. Kuenzer, editors. The Mekong delta system: interdisciplinary analyses of a river delta. Springer, Dordrecht, the Netherlands. https://doi.org/10.1007/978-94-007-3962-8_1

Renaud, F. G., L. T. T. Huong, C. Lindener, V. T. Guong, and Z. Sebesvari. 2015. Resilience and shifts in agro-ecosystems facing increasing sea-level rise and salinity intrusion in Ben Tre Province, Mekong Delta. Climatic Change 133(1):69-84. https://doi. org/10.1007/s10584-014-1113-4

Resilience Alliance. 2007. Assessing and managing resilience in social-ecological systems: a practitioners workbook. Resilience Alliance.

Resilience Alliance. 2010. Assessing resilience in social-ecological systems: workbook for practioners. Resilience Alliance.

Schwab, M., C. Berchtold, and A. Goris. 2016. An integrated critical infrastructure risk and resilience concept in the context of extreme weather events and global change. Journal of Extreme Events 3(4):1650015. https://doi.org/10.1142/S2345737616500159

Smajgl, A., T. Q. Toan, D. K. Nhan, J. Ward, N. H. Trung, L. Q. Tri, V. P. D. Tri, and P. T. Vu. 2015. Responding to rising sea levels in the Mekong Delta. Nature Climate Change 5:167-174. https:// doi.org/10.1038/nclimate2469

Tanner, T., D. Lewis, D. Wrathall, R. Bronen, N. Cradock-Henry, S. Huq, C. Lawless, R. Nawrotzki, V. Prasad, M. A. Rahman, R. Alaniz, K. King, K. McNamara, M. Nadiruzzaman, S. HenlyShepard, and F. Thomalla. 2015. Livelihood resilience in the face of climate change. Nature Climate Change 5:23-26. https://doi. org/10.1038/nclimate2431

Tessier, O. 2011. Outline of the process of Red River hydraulics development during the Nguyễn dynasty (nineteenth century). Pages 45-68 in M. A. Stewart and P. A. Coclanis, editors. Environmental change and agricultural sustainability in the Mekong Delta. Springer, Dordrecht, the Netherlands. https://doi. org/10.1007/978-94-007-0934-8 4

Tho, N., N. Vromant, N. T. Hung, and L. Hens. 2008. Soil salinity and sodicity in a shrimp farming coastal area of the Mekong Delta, Vietnam. Environmental Geology 54(8):1739-1746. https:// doi.org/10.1007/s00254-007-0951-Z

Thuy, T. H. N., and A. Ford. 2010. Learning from the neighbors: economic and environmental impacts from intensive shrimp farming in the Mekong Delta of Vietnam. Sustainability 2 (7):2144-2162. https://doi.org/10.3390/su2072144

Tien, T. D., N. P. Le, and S. P. Marsh. 2006. Agricultural land use flexibility in Vietnam. Pages 41-68 in S. P. Marsh, T. G. MacAulay, and P. V. Hung, editors. Agricultural development and land policy in Vietnam. Australian Centre for International Agricultural Research, Canberra, Australian Capital Territory, Australia.

Toth, A., S. Rendall, and F. Reitsma. 2016. Resilient food systems: a qualitative tool for measuring food resilience. Urban Ecosystems 19(1):19-43. https://doi.org/10.1007/s11252-015-0489-X

Tu, N. M., F. G. Renaud, and Z. Sebesvari. 2019. Drivers of change and adaptation pathways of agricultural systems facing increased salinity intrusion in coastal areas of the Mekong and Red River deltas in Vietnam. Environmental Science and Policy 92:331-348. https://doi.org/10.1016/j.envsci.2018.10.016 
Tuan, N. D. A. 2010. Land policy in Vietnam's agrarian transition: a case study of Namdinh Province. Pages 109-128 in M. Spoor, N. Heerink, and F. Qu, editors. Dragons with clay feet? Transition, sustainable land use, and rural environment in China and Vietnam. Lexington Books, Lanham, Maryland, USA.

Tuan, L. A., C. T. Hoanh, F. Miller, and B. T. Sinh. 2007. Flood and salinity management in the Mekong Delta, Vietnam. Pages 15-68 in T. T. Be, B. T. Sinh, and F. Miller, editors. Challenges to sustainable development in the Mekong Delta: regional and national policy issues and research needs. Sustainable Mekong Research Network, Bangkok, Thailand.

Ungar, M. 2003. Qualitative contributions to resilience research. Qualitative Social Work 2(1):85-102. https://doi.org/10.1177/14$\underline{73325003002001123}$

Ungar, M., and L. Liebenberg. 2011. Assessing resilience across cultures using mixed methods: construction of the child and youth resilience measure. Journal of Mixed Methods Research 5 (2):126-149. https://doi.org/10.1177/1558689811400607

United Nations Development Programme (UNDP). 2016. Viet Nam drought and saltwater intrusion: transitioning from emergency to recovery. Analysis report and policy implications. UNDP, Hanoi, Vietnam.

van Dijk, M., H. Hilderink, W. van Rooij, M. Rutten, R. Ashton, K. Kartikasari, and V. C. Lan. 2013. Land-use change, food security and climate change in Vietnam: a global-to-local modelling approach. LEI, Wageningen UR, The Hague, the Netherlands.

Vinh, V. D., S. Ouillon, T. D. Thanh, and L. V. Chu. 2014. Impact of the Hoa Binh dam (Vietnam) on water and sediment budgets in the Red River basin and delta. Hydrology and Earth System Sciences 18(10):3987-4005. https://doi.org/10.5194/hess-18-3987-2014

Wagner, F., V. B. Tran, and F. G. Renaud. 2012. Groundwater resources in the Mekong Delta: availability, utilization and risks. Pages 201-220 in F. G. Renaud and C. Kuenzer, editors. The Mekong Delta system: interdisciplinary analyses of a river delta. Springer, Dordrecht, the Netherlands. https://doi. org/10.1007/978-94-007-3962-8 7

Walker, B., C. S. Holling, S. R. Carpenter, and A. Kinzig. 2004. Resilience, adaptability and transformability in social-ecological systems. Ecology and Society 9(2):5. https://doi.org/10.5751/ ES-00650-090205

Walker, B., J. Sayer, N. L. Andrew, and B. Campbell. 2010. Should enhanced resilience be an objective of natural resource management research for developing countries? Crop Science 50 (S1):S-10-S-19. https://doi.org/10.2135/cropsci2009.10.0565

Wooldridge, J. M. 2010. Econometric analysis of cross section and panel data. Second edition. MIT Press, Cambridge, Massachusetts, USA.

Ye, L., S. Jiang, X. Zhu, Q. Yang, W. Wen, and K. Wu. 2009. Effects of salinity on growth and energy budget of juvenile Penaeus monodon. Aquaculture 290(1-2):140-144. https://doi. org/10.1016/j.aquaculture.2009.01.028

Yen, N. T. B., A. Kamoshita, D. T. H. Van, H. Matsuda, and H. Kurokura. 2017. Salinity intrusion and rice production in Red River Delta under changing climate conditions. Paddy and Water Environment 15(1):37-48. https://doi.org/10.1007/s10333-016-0526-2 
Appendix 1. Median values of perceived support received from the government and other farmers for the interviewed farmers in the Mekong Delta (interquartile ranges in parentheses).

\begin{tabular}{lrr}
\hline \multicolumn{1}{c}{ Farming systems } & Support from the government & \multicolumn{1}{c}{ Support from other farmers } \\
\hline Rice & $3.0(2.0-4.0)$ & $4.0^{a}(2.0-4.0)$ \\
Rice-shrimp & $2.0(1.5-4.0)$ & $3.0^{b}(2.0-4.0)$ \\
Shrimp & $3.0(2.0-4.0)$ & $4.0^{a}(2.0-4.0)$ \\
\hline
\end{tabular}

The values in the table represent a "1-5 Likert scale" standing for: very little (1) to very much (5) support. No significant difference of support from the government between farming systems $(\chi 2(2)=1.34, p=$ $0.512)$, significant difference of support from other farmers between farming systems $(\chi 2(2)=8.28, p=$ $0.016)$. The median values with different superscripts are significantly different ( $p$-value $<0.05$, Dunn's test) 
Appendix 2. Median values of perceived support from the government and other farmers for the interviewed farmers in the Red River Delta (interquartile ranges in parentheses).

\begin{tabular}{lcccccc}
\hline $\begin{array}{c}\text { Perceived } \\
\text { support from }\end{array}$ & Double rice & Rice-vegetable & Vegetable & Fish pond & $\begin{array}{c}\text { Soft-shell } \\
\text { turtle }\end{array}$ & $\begin{array}{c}\text { Large fish } \\
\text { pond }\end{array}$ \\
\hline Government & $2.0(2.0-3.0)$ & $2.0(2.0-3.0)$ & $3.5(2.0-4.0)$ & $2.0(1.0-2.5)$ & $2.5(1.0-3.0)$ & $1.5(1.0-2.0)$ \\
Other farmers & $4.0(2.0-4.0)$ & $3.5(2.0-4.0)$ & $3.5(2.0-5.0)$ & $4.0(2.0-4.0)$ & $4.0(4.0-5.0)$ & $4.0(2.0-4.0)$ \\
\hline
\end{tabular}

The values in the table represent a "1-5 Likert scale" standing for: very little (1) to very much (5) support. No significant difference of perceived supports from the government $(\chi 2(5)=10.33, p=0.067)$ and other farmers $(\chi 2(5)=5.36, p=0.374)$ between farming systems 
Appendix 3. Ordinal logistic regression models on resilience components and socio-economic characteristics of households in the Mekong Delta.

\begin{tabular}{|c|c|c|c|c|c|c|}
\hline \multirow[b]{2}{*}{ Independent variables } & \multicolumn{2}{|c|}{ Sensitivity } & \multicolumn{2}{|c|}{ Capacity to recover } & \multicolumn{2}{|c|}{ Capacity to change } \\
\hline & Coeff. & Std. Err & Coeff. & Std. Err & Coeff. & Std. Err \\
\hline Farm type (rice/rice-shrimp/shrimp) & -0.127 & 0.189 & -0.079 & 0.193 & -0.252 & 0.196 \\
\hline Age of the household head (years) & -0.010 & 0.013 & -0.001 & 0.012 & 0.003 & 0.013 \\
\hline $\begin{array}{l}\text { Education of the household heads (1: No schooling; } 2 \text { : } \\
\text { Primary school, 3: Secondary school; 4: High school; 5: } \\
\text { Higher education e.g. university, college, vocational degrees) }\end{array}$ & -0.070 & 0.150 & 0.074 & 0.141 & -0.179 & 0.147 \\
\hline Wealth categories (poor/average/better off) & 0.435 & $0.235^{*}$ & 0.164 & 0.222 & -0.382 & $0.220^{*}$ \\
\hline Gender of household head & -0.268 & 0.436 & -0.803 & $0.438^{*}$ & 0.404 & 0.429 \\
\hline $\begin{array}{l}\text { Soil characteristics of the largest parcel (high/medium/low } \\
\text { acid sulphate soils) }\end{array}$ & 0.295 & $0.156^{*}$ & 0.029 & 0.156 & -0.294 & $0.157^{*}$ \\
\hline $\begin{array}{c}\text { Farm size in ha (including all different fields, also of other } \\
\text { farming systems) }\end{array}$ & 0.030 & 0.077 & 0.005 & 0.078 & -0.122 & 0.079 \\
\hline House size in square meters & -0.005 & $0.003^{* *}$ & 0.003 & 0.002 & 0.005 & $0.002 * *$ \\
\hline Access to road in both seasons & -0.400 & 0.326 & -0.116 & 0.333 & -0.056 & 0.334 \\
\hline Having family member with chronic illness & -0.238 & 0.313 & -0.983 & $0.313 * * *$ & 0.363 & 0.314 \\
\hline Access to loan & 0.362 & 0.286 & -0.445 & 0.297 & -0.095 & 0.290 \\
\hline Member of organization & 0.444 & 0.295 & 0.634 & $0.288 * *$ & -0.739 & $0.305^{* *}$ \\
\hline Receiving remittance & 0.030 & 0.401 & 0.814 & $0.416^{*}$ & -0.140 & 0.405 \\
\hline Having off-farm income & 0.205 & 0.277 & 0.092 & 0.274 & 0.142 & 0.279 \\
\hline Household size & -0.005 & 0.096 & -0.173 & $0.094 *$ & 0.031 & 0.093 \\
\hline $\mathrm{N}$ & \multicolumn{2}{|c|}{193} & \multicolumn{2}{|c|}{192} & \multicolumn{2}{|c|}{193} \\
\hline LR chi2(16)/ Prob>chi2 & \multicolumn{2}{|c|}{$21.54 / 0.121$} & \multicolumn{2}{|c|}{$29.28 / 0.015$} & \multicolumn{2}{|c|}{$21.04 / 0.136$} \\
\hline Pseudo $\mathrm{R}^{2} /$ Log likelihood & \multicolumn{2}{|c|}{$0.030 /-346.49$} & \multicolumn{2}{|c|}{$0.039 /-359.35$} & \multicolumn{2}{|c|}{$0.035 /-288.41$} \\
\hline
\end{tabular}

Notes: ***Significant at the $1 \%$ level. **Significant at the $5 \%$ level. *Significant at the $10 \%$ level. 